\title{
Energy based surgical instruments - With particular focus on collateral thermal injury
}

\author{
Johan Carlander
}

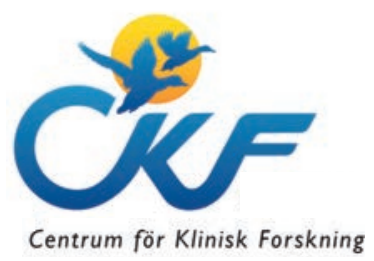

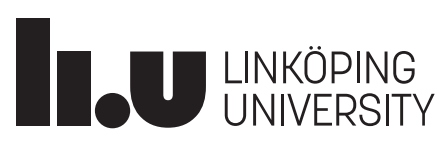

Department of Clinical and Experimental Medicine,

Linköping University, Linköpings universitet, SE-581 83 Linköping, Sweden

Centre for Clinical Research, County of Västmanland, Uppsala University, SE-721 89 Västerås, Sweden 
(c) Johan Carlander, 2015

Graphic design \& cover: Stina Janson

All previously published papers were reproduced with permission from the publisher.

Printed in Sweden by LiU-Tryck, Linköping, Sweden, 2015

ISBN 978-91-7685-902-5

ISSN 0345-0082 


\section{Energy based surgical instruments - With particular focus on collateral thermal injury}

Johan Carlander

November 2015

Linköping University medical dissertations

No. 1491

ISSN 0345-0082 


\section{ABSTRACT}

Iatrogenic post-operative nerve dysfunction is a significant problem in many areas of surgery and can be caused by collateral thermal injury from activation of energy based surgical devices (EBD).

The aims of this thesis were to: create an animal model in order to compare mono- and bipolar electrosurgery (ES) and an ultrasonic dissection (UD) with regard to collateral thermal nerve injury, and with data of a national multicenter register to study the use of EBD and their potential effects on operation time and complication rates in thyroid surgery.

Material and Methods: The biceps femoris muscle of 104 anesthetized rats was cut in a standard manner adjacent to the sciatic nerve using clinical relevant settings of mono- and bipolar ES and UD. The sciatic nerve was stimulated supramaximally and the electromyographic (EMG) potential recorded before and after each experiment. Nerve dysfunction was defined as $>10 \%$ reduction of the evoked EMG potential. In Paper II and III temperature was measured before, during and after instrument activation. The sciatic nerves were coded and examined blinded with light (LM) and electron microscopy. Advanced temperature measurements were conducted in Paper II and III. In Paper IV, the use of EBD was specifically registered in the Scandinavian Quality Register for Thyroid, Parathyroid and Adrenal Surgery (SQRTPA) during one year and 1297 patients were included. Operation time, recurrent laryngeal nerve (RLN) injury, post-operative hypoparathyroidism and the use of topical haemostatic agents were compared between bipolar ES, electric vessel sealing (EVS) and UD. Clamp and Tie technique (C-A-T) being without thermal risk constituted the control group.

Results: In Paper I the EMG potential was significantly more frequent reduced in the monopolar and bipolar ES group compared to the UD group and LM showed significantly less nerve damage in the UD group. In Paper II exact temperature measurements was possible with thermo- 
electric micros sensors and the thermal dose was significantly less and with less variation for the UD compared to the bipolar ES. Similar to the Paper I the EMG potential was significantly more frequent reduced in the ES group. Moderate and severe morphological damage was significantly less common in the UD group compared to monopolar ES. We found no statistical correlation between the highest temperatures/doses and the degree of morphological damage or functional loss. In Paper III the temprature increase was significantly less and with shorter duration in the UD group, compared to biplar ES. LM and EM demonstrated loss of density in the myelin sheet only in a small number of nerves in all groups after instrument activation $1 \mathrm{~mm}$ from the nerve.

In Paper IV, operation time was significantly shorter in the UD group and significantly longer in the EVS and bipolar ES group, compared to C-A-T. Postoperative hypoparathyroidism with need for Calcium treatment at discharge and at 6 weeks was significantly higher with ES instruments compared to UD. The incidence of reported RLN injury was $2.5 \%$ at 6 weeks postoperatively without statistical differences between the groups. Topical haemostatic agents were more frequently used in the EBD groups compared to C-A-T.

Conclusion: The experimental Papers (I-III) demonstrated a lower risk of adverse collateral thermal nerve injury with activation of the mechanical UD technique compared to ES techniques. In the nationwide multicenter register Paper (IV), the use of UD shortened end EVS increased operation time compared to the low cost C-A-T. The UD instruments had a lower risk of hypoparathyroidism than electrosurgery.

Keywords: Energy based surgical devices, collateral thermal spread, nerve injury

Department of Clinical and Experimental Medicine

Linköpings Universitet

SE-581 83 Linköping, Sweden 
"It always seems impossible until it's done"

Nelson Mandela 


\section{List of papers}

I

Carlander J, Johansson K, Lindström S, Velin A.K, Jiang

C. H, Nordborg C.

Comparison of experimental nerve injury caused by

ultrasonicall activated scalpel and electrosurgery

Br J Surg. 2005 Jun; 92(6): 772-7.

II

Carlander J, Koch C, Brudin L, Nordborg C, Gimm O, Johansson $\mathrm{K}$.

Heat production, nerve function, and morphology

following nerve close dissection with surgical instruments

World J Surg. 2012 Jun; 36(6): 1361-7

III

Carlander J, Defechereux T, Koch C, Cheramy JP,

Deprez M, Johansson K.

Risk of nerve injury after use of energy based surgical devices

Submitted to Br J Neurosurgery

IV Carlander J, Gimm O, Nordenström E, Jansson S, L.Bergqvist, Johansson K.

Risk of complications with Energy-based surgical devices in thyroid surgery- A national multicenter register study

In press, World J Surg

Reprints were made with the permission of the publishers 


\section{Contents}

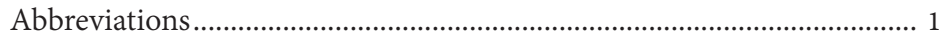

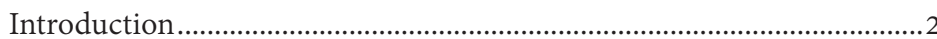

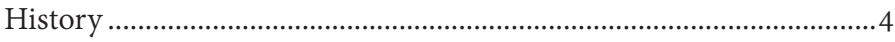

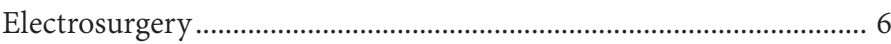

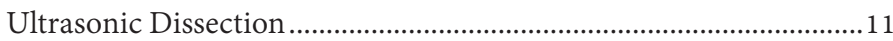

Thermal impact of Tissue ..................................................................12

Advantages and disadvantages of EBDs ................................................. 14

EBDs and adverse events .................................................................15

Clinical important fields ......................................................................15

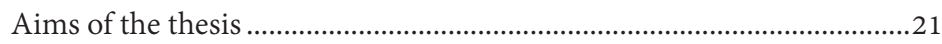

Material and methods ..............................................................................22

Surgical Procedure Papers I-III.................................................................22

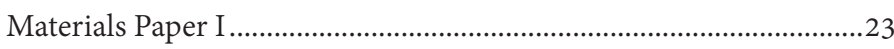

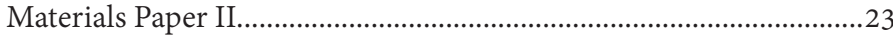

Materials Paper III ...............................................................................23

Functional Studies Paper I-III ..............................................................24

Morphological Studies Paper I-III .......................................................25

Temperature Measurements Papers II-III.............................................26

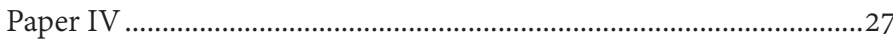

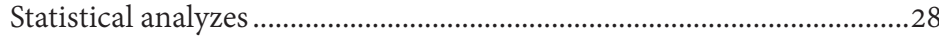

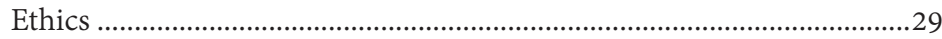

Conflict of interest........................................................................................29

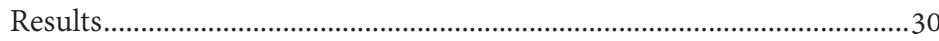

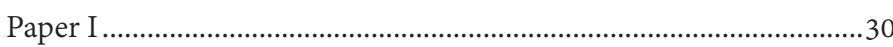

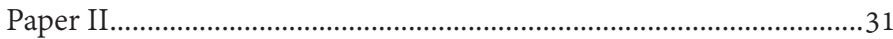

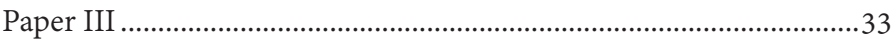

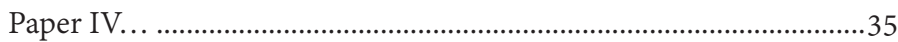

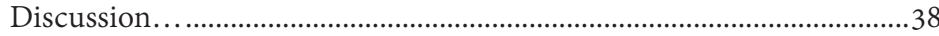

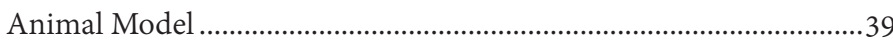

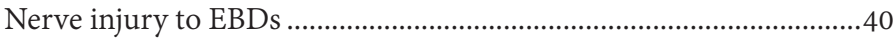

Thermal spread by EBDs.........................................................................42 


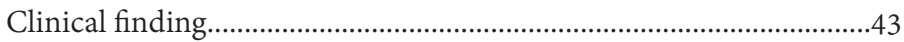

Methodological Considerations ................................................................

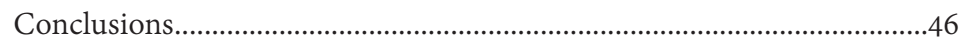

Future perspective ...............................................................................

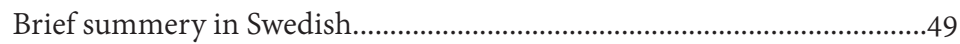

Acknowledgements ...............................................................................

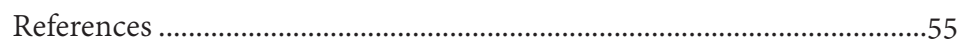





\section{Abbreviations}

C-A-T Cut and tie

DC Direct current

EBD Energy based surgical device

EB External branch

EM Electron microscope

EMG Electromyographic potential

ES Electrosurgery

ESU Electrosurgical unit

EVS Electric vessel sealer

LM Light microscope

OR Odds ratio

RCT Randomized clinical trial

RF Radio frequency

RLN Recurrent laryngeal nerve

SQRTPA The Scandinavian Quality Register for Thyroid, Parathyroid, and Adrenal Surgery

SLN Superior laryngeal nerve

UD Ultrasonic dissection

VCP Vocal cord paresis 


\section{Introduction}

Most of the surgical procedures involve the use of a device that applies energy to cut and coagulate tissues. The energy delivered by these instruments raises the temperature in the tissue and causes lateral spread of heat to the surrounding tissue. The degree of lateral thermal spread depends on the type of surgical device, type of tissue, blood perfusion, the power settings used and the duration of application. Collateral spread of temperature in the tissue can cause iatrogenic nerve injuries and is a significant clinical problem in different surgical areas. Following rectal cancer operations $15-40 \%$ of patients report sexual and urinary dysfunction [1-3], 70-90\% of male patients suffer from impotence after prostatectomy $[4,5]$, and after thyroid surgery damage to the recurrent laryngeal nerve (RLN) has an incidence of 5-7\% for temporary injuries and $0.9-2.4 \%$ for permanent injuries[6-8], the reported incidence of hypocalcemia ranges from $7-46 \%[9,10]$. The ideal energy-based surgical device (EBD) would be one with perfect hemostasis with minimum damage to the surrounding tissue.

Surgeons need good knowledge on the underlying working principles of the EBD and on biophysical tissue interactions [11], as the technology between EBD differs. In addition, the introduction of new surgical tools has occurred at an increasing rate the last decade without formal education about usage and safety; this is in contrast to the introduction of new pharmaceuticals. New drugs are required to have 2 separate double blinded RCTs for approval by the U.S. Food and Drug Administration, new devices for human use are not subject to this same standard. Each EBD has advantages and disadvantages and surgeons put themselves and their patients at risk without this knowledge. Consequently, many surgeons have extensive experience with an instrument that they may not fully understand [11].

Radiofrequency electrosurgery (ES) is used in almost every operating room across the world. There are different types of electrosurgery, with the most common being monopolar and bipolar ES, and electric vessel 
sealers (EVS). All ES sends an electric current through the tissue, and the ES devices cause a considerable increase in temperature in the surrounding tissue [12-14]. An alternative technique for surgical dissection is ultrasonic dissection (UD) which uses mechanical energy from vibrations at $55 \mathrm{kHz}$ that disrupt the hydrogen bonds in tissue proteins and leads to division of the tissue. There are conflicting results according collateral thermal spread from EBDs, some have conlcuded a reduced propensity to cause collateral thermal damage in UD $[15,16][17]$ compared to ES.

Despite the growing and widespread usage of EBD there has been paucity in the literature where these devices have been scientifically tested. Many studies are sponsored by manufacturers and in meta-analysis of these studies, and for example, operating time is substantially shorter than in investigator-initiated trials [18]. Meta-analyses are made, but many are based on only a small number of randomized clinical trials (RCT) $[19,20]$.

There are still a lot of questions concerning spread of energy in the tissues surrounding the working area. How far from the device can you see injuries to nerves and other sensitive tissues? What temperatures are induced? What kind of injury can be seen in light microscope and electron microscope? Do the changes seen in the laboratory mean anything in the clinical setting? 


\section{History}

Before the introduction of antibiotics, thermal cautery was a widespread technique in wound treatment. A piece of metal was heated over fire and then applied to the wound. The rapid temperature increase would cauterize the wound leading to disinfection and control of bleeding. These cauters had different shapes and sizes depending on the application. As early as $3000 \mathrm{BC}$ Egyptians used this technique to treat tumors and to control hemorrhage after trauma [21]. In approximately 500 BC Hippocrates favored cautery as a treatment for destroying lesions when other methods failed. Through the ages applications included hemostasis, tumor destruction, and even for opening short segments of imperforate anus.

The first electrical energy used in medicine was direct current (DC). In the mid-eighteenth century Becquerel started to use DC instead of heated oil. The DC heated surgical instrument was to be applied to the tissue, this acted as a form of cautery [22]. Modern electrosurgery began at the start of the 20th century when Alex d'Arsonval demonstrated radio frequency currents could heat living tissue without painful muscle and nerve stimulation [23]. In the late 1920s Harvard physicist and botanist, William Bovie produces the first a commercial machine capable of cutting and coagulating human tissue (Figure 1), and added an instrument that was handheld with a pistol grip. Dr Harvey Cushing, neurosurgeon in Boston, popularized this electro surgical unit by performing surgical procedures previously considered impossible [24]. On the 1st of October 1926, Dr Cushing removed the remains of a vascular myeloma that a few days earlier he had abandoned due to excessive vascularity. In Dr Cushing's notes he wrote, “... with Dr. Bovie's help I proceeded to take off most satisfactorily the remaining portion of tumor with practically none of the bleeding which was occasioned in the preceding operation." The results of this and other procedures were published in 1928 [25] and gave birth to modern clinical electrosurgery. Dr Bovie never made any money on his invention; he sold his patent for one USD to the company Libel-Flarsheim. 


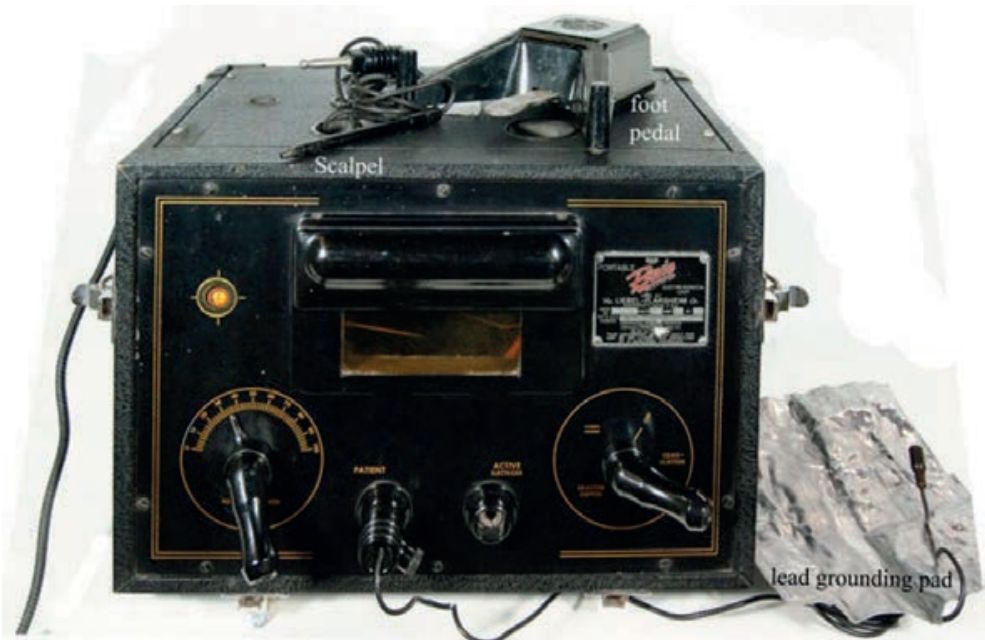

Figure 1: An early electro surgical "Bovie" unit from the late 1920 s.

Printed with permission.

During the 1940s neurosurgeon James Greenwood, at Methodist Hospital, Houston, Texas, USA, introduced bipolar technology. The instrument was modified by another neurosurgeon Leonard Malis, at Mount Sinai New York, into the bipolar device we know today. In this instrument, the electric current only flowed between two electrodes. The development of monopolar and bipolar instruments has continued up to present time, but at a faster pace.

In the early 1960s, ultrasonic energy began to be used in medicine to treat Ménières disease. In the late 1980s Tom Davidson and colleagues started to investigate the use of ultrasonic dissection, and were pioneers in developing the first ultrasonic scalpel at the department of Dermatology, University of Pittsburgh[26]. In the mid 1990s, , Joseph Amaral, an early collaborator of Tom Davidson reported [27] results from experimental studies with ultrasonically generated dissection, and later, successfully used UD in more than 200 patients that underwent laparoscopic cholecystectomy; thus indicating that ultrasonic energy delivered through ultrasonic dissection was safe and produced a limited amount of thermal spread. 


\section{Background: Basic principles of different types of EBD Electrosurgery}

The most common electrosurgery technique that combines cutting with coagulation for hemostasis is monopolar or bipolar ES. The basis is a potential difference between two electrodes providing a path of least resistance. In electrosurgery, heat is generated in the tissue by the flow of radio frequency (RF) electric current [28], unlike the process of cautery, derived from the Greek word kauterion (hot iron). A current in the range of 300-500 kHz eliminates the painful neuromuscular stimulation that ceases above $100 \mathrm{kHz}$. During RF electrosurgery, electromagnetic energy is converted into kinetic energy and then into thermal energy. When the electrical current is concentrated in a small area in the tissue, typically by applying the energy through a pointed tip increases in the cellular temperature create the tissue effects. The current then follows the path of least resistance towards the dispersive pad. The three interacting properties of electricity that affect the temperature rise in tissue are current (I), voltage (V), and impedance or resistance (R) according to Ohms Law.

\section{All RF Electrosurgery is "Bipolar" Monopolar vs Bipolar Instrumentation}

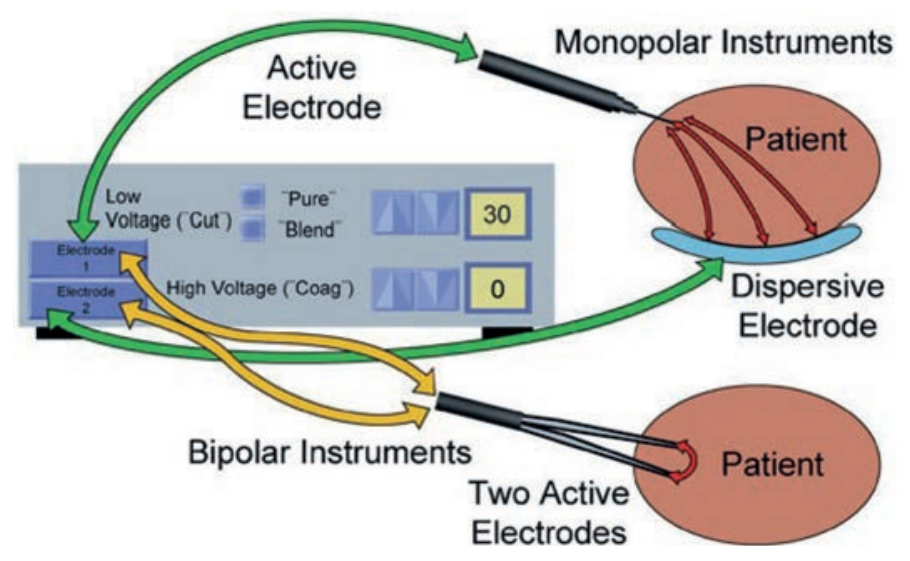

Figure 2: All electrosurgery is "bipolar" it is the location and purpose of the second electrode that varies. Monopolar systems include the entire patient in the circuit. Printed with permission. 


\section{Electrosurgical generators}

Electrosurgical generators convert low frequency AC $(60 \mathrm{~Hz})$ from a wall outlet into higher-voltage RF, typically between $300-500 \mathrm{kHz}$ because this allows for desired thermal effects without muscle fasciculation or nerve stimulation. Voltage is the amount of force the electrosurgical generator must supply to push the electrons through the tissue; it is measured in volts. The current is a flow of electrons from the generator, through the active electrode and through the patient's tissue during a period, and is measured in amperes. The electrosurgical unit (ESU) is also capable of creating different waveforms that allow the surgeon to change the impact of the energy, for example between cutting and coagulation. The new generation of ESU uses higher currents but less voltage, and has impedance and endpoint feedback [29], that results in less thermal spread and more effective activation; however, they are more costly.

\section{Monopolar electrosurgery}

In monopolar ES, concentrated current is sent through the body from an active electrode at the surgical site, through the body to a remote ground pad attached to the patient [28] (Figures 2, 3). The active electrode comprises many forms, for example a point, hook, or a blade, with sharp and blunt edges. Electrodes with sharp edges increase the density of the current and are used for cutting, whereas blunt edges are used for coagulation. A narrow tip allows the current to be concentrated and generate a large amount of heat, above $100^{\circ} \mathrm{C}$ which induces cutting. With a blunt instrument tip, there is decreased current concentration due to the increased surface area, and the tissue temperature does not reach $100^{\circ} \mathrm{C}$; instead, at temperatures between $50-80^{\circ} \mathrm{C}$, the tissue coagulates. The ground pad is wide and disperses the heat, and leads the current out of the body. The monopolar instruments are approved to divide vessels $\leq 2 \mathrm{~mm}$ in diameter[30]. 


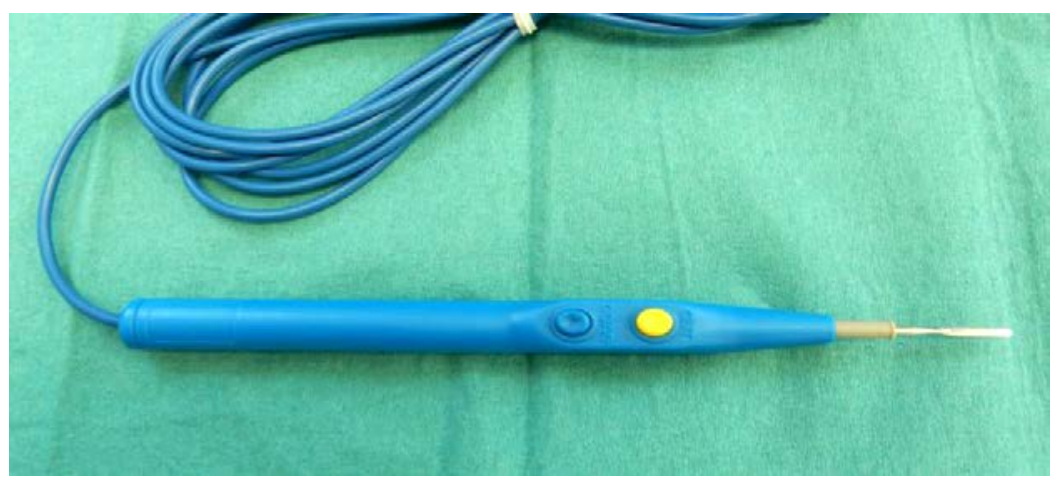

Fig 3: Monopolar electrosurgery

\section{Bipolar Electrosurgery}

In bipolar ES, the active and the return electrodes are similar in size and in close proximity to one another (Figures 2,4 ). The voltage required in bipolar ES is usually low due to the short distance between the electrodes [31] and only the tissue grasped is included in the electrical circuit. This lower voltage results in a better hemostasis of the tissue, which makes bipolar instruments more suitable for coagulation rather than cutting [32]. Bipolar ES provide better seal quality, lesser blood loss and have smaller thermal spread compared to Monopolar ES [33, 34]

Newer electric vessel sealers (EVS) use direct application of pressure and radiofrequency current released in a precise and calibrated way to achieve hemostasis, and tissue sealing [35]. When the instruments are closed on the tissues, its energy denatures the collagen and elastin in the vessel wall allowing protein to form a seal at a temperature between $60-90^{\circ} \mathrm{C}$ rather than creating a proximal thrombus. EVS modulate the quantity of energy by applying appropriate pressure to the grip [36] and there is less lateral thermal spread compared to traditional ES. The EVS seal blood vessels up to $7 \mathrm{~mm}$ [37-39]. 


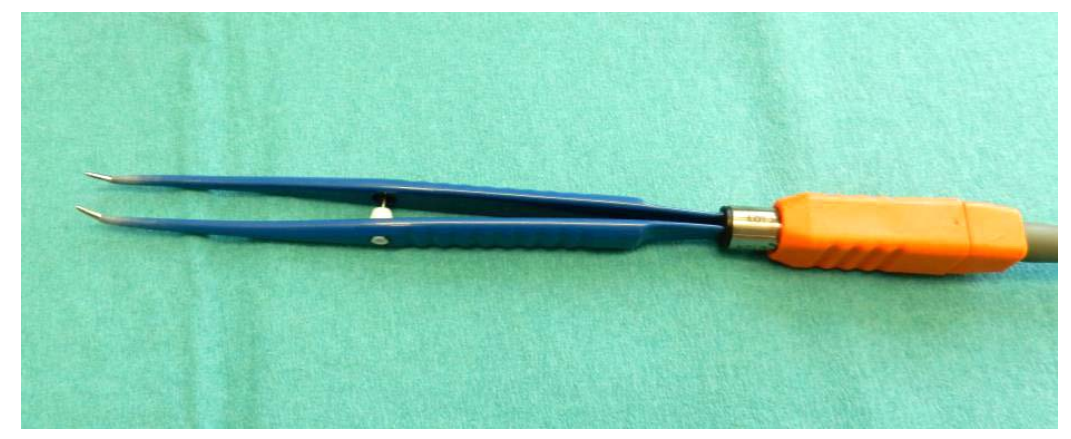

Figure 4: Bipolar Electrosurgery, scissors and forceps.

\section{Waveform of electrosurgery}

The waveform of the current must be considered for understanding the surgical effect of electrosurgery. Different duty cycles (percentage of time the energy is applied) are applied by the electrosurgical generator in order to produce the different tissue responses during electrosurgery. By intermittently stopping the current flow (modulating the waveform), tissue has a chance to cool and the portion of cells that desiccate without exploding increases. By balancing how frequently the current flows (duty cycle) with increasingly higher voltage peaks, the waveform designer can predict tissue effects that have increasingly deep margins of coagulation, and the user can expect deeper hemostasis. Cutting waveforms are sine waves, where the generator supplies 100\% current in an alternating, continuous fashion. Lower duty waveforms, with short bursts of sine waves, are used for coagulation. Higher voltages are required for coagulation mode, to force the current through highly resistant, desiccated tissue. Blend-Cut mode employs a waveform and voltage that is between cutting and coagulation. Spray coagulation or fulguration is a very high voltage waveform in which the generator supplies current for only $6 \%$ of the generator's cycle. The high voltage is necessary to generate electrical sparks from the active electrode to the tissue in order to produce superficial low-heat desiccation. 


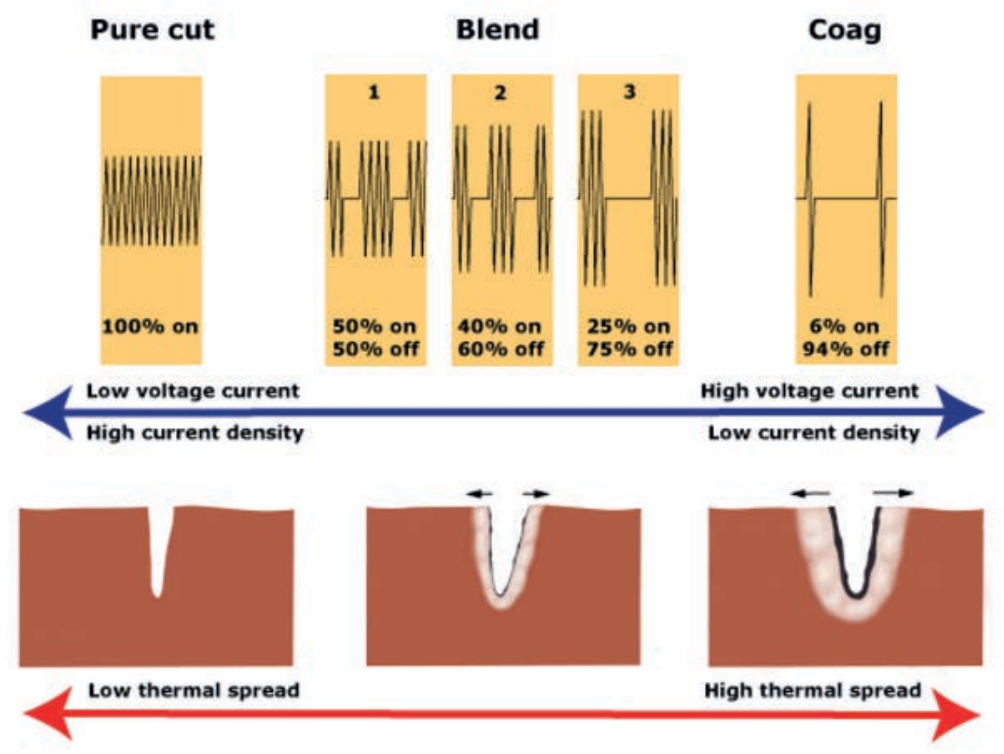

Figure 5: Thermal spread in tissue. Printed with permission.

\section{Safety Factors}

There is a large quantity of literature on the possible hazards of monopolar electrosurgery, as it is the oldest and best-studied energetic dissection technique [40]. Four different injury patterns are usually distinguished. Direct application describes sustained damage through wrong positioning of the electrodes or device misuse. Direct coupling refers to the unintended contact of the active electrode to other conductive materials within the surgical field [41]. Insulation failure is caused by a defect in the insulation or coating, often as result of from excessive use and sterilization $[42,43]$. Capacitive coupling refers to the capacitor mechanism, where electrical potential buildup occurs between nearby materials without making actual contact [11]. An intact insulator shields the direct flow of current, but the attraction of charged particles across the insulator remains. In addition, monopolar ES have trouble operating in a conductive medium, as this alters the path of least resistance. 


\section{Ultrasonic Dissection}

Ultrasonic devices work by means of a piezoelectric element. A transducer activated electrically creates a potential difference across the piezoelectric element (Figure 6). The polarity changes induce vibrations with the same frequency as in the piezoelectric material [44], and this vibrational energy is subsequently led to the working tip of the device that oscillates in a linear fashion. The energy supplied causes collagen denaturation and breaks hydrogen bonds between collagen and other extracellular matrix proteins in the tissue[45], through internal cellular friction being caused by the vibrations in absence of an electrical current in the tissue [46]. The ultrasonic devices usually works at a frequency of $23-55 \mathrm{kHz}$, and the amount of mechanical energy is adjusted by varying the length of excursion of the blade, the range can be adjusted between 50-100 $\mu \mathrm{m}$. There are usually two settings for the device, MAX and MIN. The MAX setting with maximum excursion result in more rapid cutting and less thermal spread, and the MIN setting results in better hemostasis but greater thermal spread and less degree of cutting. The cutting and coagulation in ultrasonic dissection depend on grip pressure, the shape and area of the blades, and the power setting [47]. With greater pressure, there is more cutting but less tissue coagulation. Ultrasonic devices produce less heat than electrosurgery $[16,17,38,48$, 49], and can be used to coagulate tissue, and are documented to divide blood vessels up to $5 \mathrm{~mm}$ [39].

The mechanism of tissue temperature rise is different to electrosurgery. The tissue is heated by external mechanical forces and coagulation occurs when the temperature rises above $60^{\circ} \mathrm{C}$ but remains below $100^{\circ} \mathrm{C}$ $[50,51]$. 


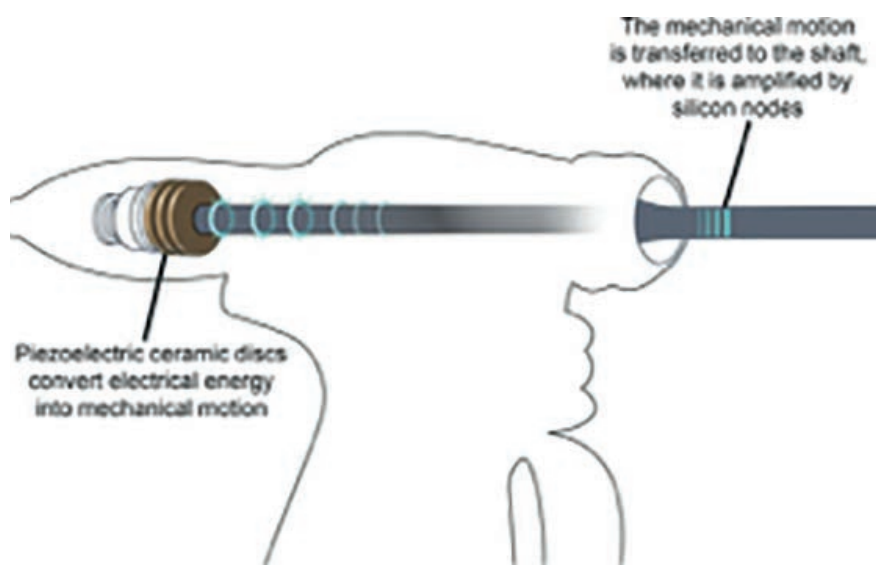

Figure 6: Ultrasonic dissection. Ultrasonic shears handset contains piezoelectric ceramic discs that convert electrical energy into mechanical motion, which is transferred to the shaft. Printed with permission.

\section{Thermal impact of tissue}

With EBDs, the maximum temperature and thermal spread varies depending on the type of target tissue and the type of energy sources used [52]. When tissue is kept at temperatures $43-50^{\circ} \mathrm{C}$ for approximately 6 min, irreversible thermal damage start to occur $[31,53]$. In the $60-80^{\circ} \mathrm{C}$ range, tissue starts to blanch and collagen denatures, and carbonization begins. The intramolecular hydrogen bonds of protein are broken, the triple-helix structure unwinds and the highly organized crystalline structure transforms into an amorphous state $[54,55]$. Although collagen denatures, elastin networks do not. As a result, soft tissue structures shrink up to approximately one-third of their initial length. With further increase of the tissue temperature, at $90^{\circ} \mathrm{C}$, water starts to evaporate and tissue starts to dry or desiccate. At approximately $100^{\circ} \mathrm{C}$, cell walls rupture due to the swelling of the cell. If the intracellular temperature rises to $100^{\circ} \mathrm{C}$ or more, a liquid-gaseous conversion occurs as the intracellular water boils and forms steam. The subsequent massive intracellular expansion results in explosive vaporization of the cell with a cloud of steam, ions, and organic matter. The explosive force may result in acoustic vibrations that contribute to the cutting effect through the tissue. 
When the local temperature reaches higher levels, such as $200^{\circ} \mathrm{C}$ or more, the organic molecules are broken down in a process called carbonization. This leaves carbon molecules with a black and/or brown appearance, sometimes referred to as "black coagulation."

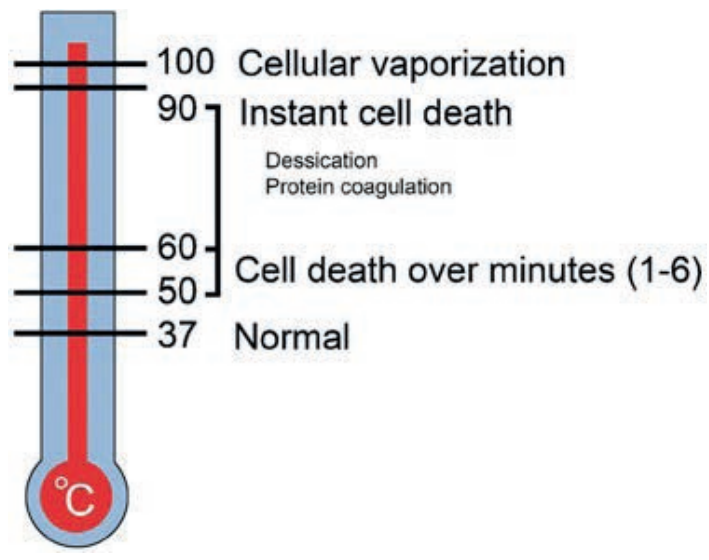

Figure 8: Tissue response to heat. If the temperature reaches $60^{\circ} \mathrm{C}$, cell death occurs instantaneously. When the intracellular temperature reaches $100^{\circ} \mathrm{C}$, cellular vaporization occurs. Printed with permission. 
General advantages and disadvantages of Energy based surgical devices:
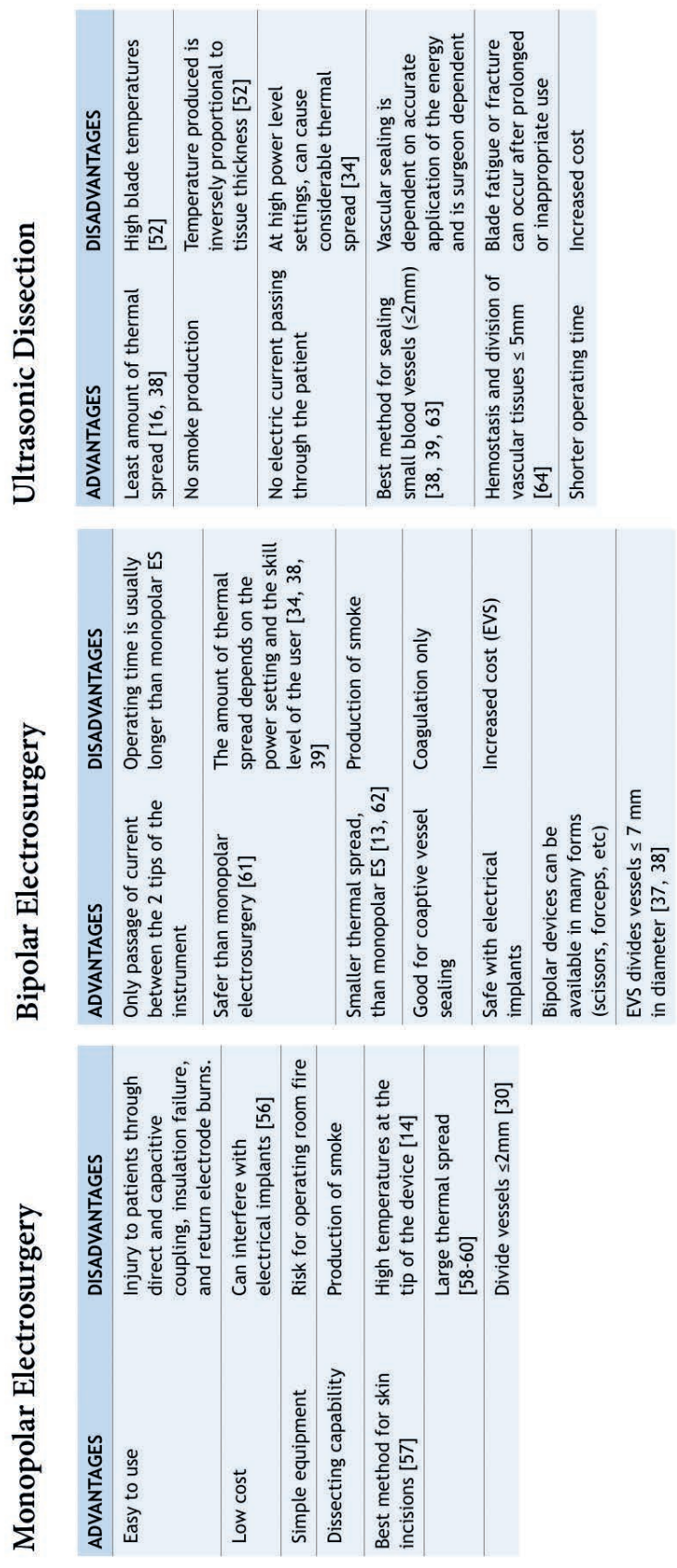


\section{EBDs and Adverse Events:}

The rate of EBD complications for an individual surgeon is low (1-2 patients per 1000 operations [65]); however from a population viewpoint, these complications are important targets for education and research.

In a register study [66] that recorded and analyzed EBD-related complications over 20 years, 178 deaths and 3553 injuries are reported: monopolar ES complications are common (45\%), followed by complications due to ablation devices (20\%), EVS (14\%), UD (9\%) and bipolar ES (7\%). Common complications include thermal burns (63\%), hemorrhage (17\%), mechanical failure (12\%), and fire ( $8 \%)$. Eight percent of injuries are attributed to residual heat, after especially UD: these results are in accordance with other results [67]. Of all events, $18 \%$ are recognized after the surgery. Hemorrhage is most frequently reported with the EVS (47\%) and UD (19\%)[66].

\section{Patterns of Injury by Device}

Dispersive electrode thermal injuries are most frequently associated with monopolar ES, whereas, direct application injury are common with bipolar ES. EVS events include hemorrhage, which is also associated with UD injuries.

\section{Clinical important fields}

\section{Thyroid Surgery}

Complications after thyroid surgery can be detrimental to the patient. The most common are postoperative hypocalcaemia, recurrent laryngeal nerve (RLN) paralysis, and hemorrhage. The thyroid gland is one of the most vascularized organs in the body, and requires careful hemostasis and EBDs are increasingly used in thyroid surgery. Previous studies have demonstrated that using EBDs significantly reduces operating time [68-71] 


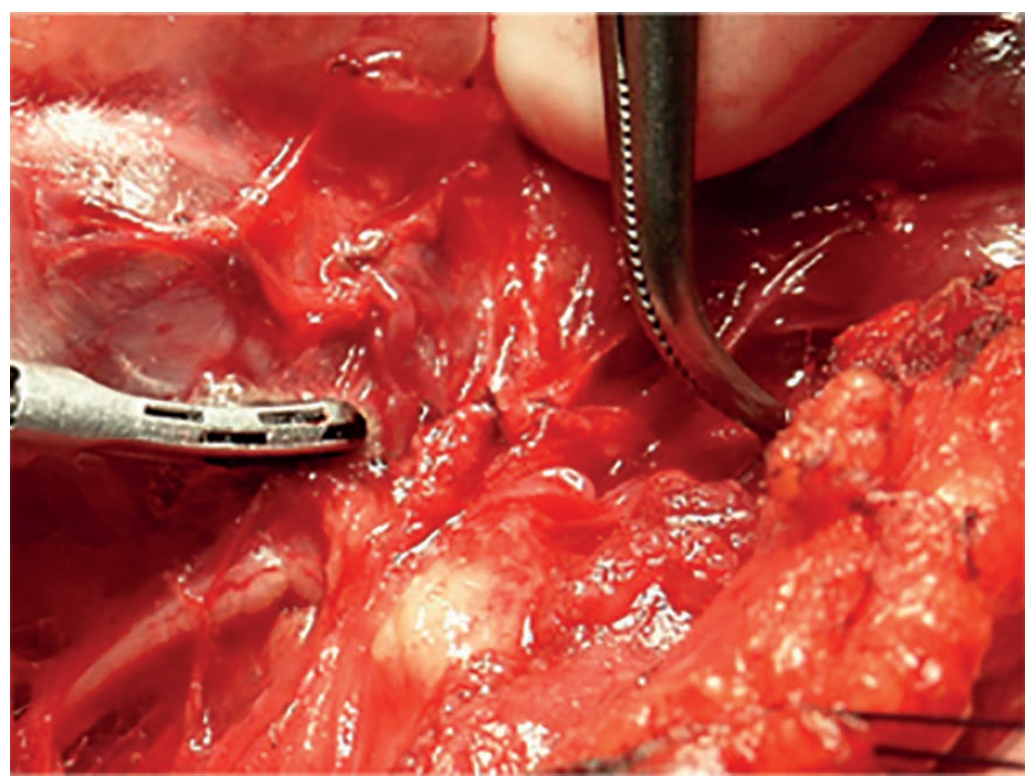

Figure 9: Thyroid surgery. Superior Laryngeal Nerve just below the EBD.

\section{Postoperative Hypocalcaemia}

Postoperative transient hypocalcaemia is the most common complication after thyroid surgery and prevalence ranges from $7-46 \%[9,72]$, due to iatrogenic injury to parathyroid blood supply. Symptoms usually appear the day after surgery and it is difficult to predict which patient will develop hypocalcaemia. Risk factors include the extent of surgery, lymph node dissection, and number of parathyroid glands identified during surgery [73-75]. Two meta-analyzes report a lower incidence of hypocalcaemia after the use of UD than with EVS and Cut-and-Tie (C-A-T) $[15,18]$. The differing effects of the EBD on the parathyroid glands might be explained by the different temperatures these instruments provide to the tissue [50]. 


\section{Recurrent Laryngeal Nerve Paralysis}

The recurrent laryngeal nerve (RLN) is a nerve consisting of motor, sensory, and autonomic nerve fibers that innervates all muscles in the larynx except for the cricothyroid muscle, which is innervated by the external branch (EB) of the superior laryngeal nerve (SLN). Damage to RLN may results in symptoms ranging from almost no symptoms to hoarseness, stridor and acute airway obstruction in bilateral paresis [76].

Incidence of recurrent laryngeal nerve injury varies among studies depending on a mix of pathologies, patient group, and surgical experience, but reported to be between 5 to $7 \%$ for temporary injury and 0.9 to $2.4 \%$ for permanent damage $[6,7]$. However, in reality, the estimation of the scale of injury after thyroid surgery is difficult, as clinicians use voice symptoms as a screening method. Laryngoscopy is only used on a subgroup of patients and the incidence of permanent vocal cord paralysis (VCP) varies greatly according to the method used to examine the larynx. The cause of injury may be mechanical due to traction or compression, transection, due to thermal spread during the operation or due to devascularisation [77-79].

The EB of SLN is also important for the voice and runs close to the superior pole vessels. It is frequently at risk when isolating those vessels. Post-operatively, patients with a lesion of this nerve typically complain of voice fatigue, problems reaching high-pitch sounds that they were used to reach, and the need of an extra effort to speak; they can also complain of various rates of dysphagia [80]. The rate of EB-SLN injury varies from 0 to $58 \%$ [81-83].

\section{Postoperative Hemorrhage}

Hemorrhage after thyroid surgery is not common but a serious complication occurring in less than $2 \%$ of procedures $[10,84]$, and may occur directly after surgery or up to days postoperatively. Hemorrhage may lead to respiratory distress and airway compression. The risk has not differed among the different EBDs in meta-analysis [18]. 


\section{Breast cancer surgery}

Monopolar and bipolar ES, UD and EVS are routinely used during operation on the breast. In treatment of patients with breast cancer, axillary lymph node dissection is required, and this surgical procedure may involve injury to the long thoracic nerve [85-87] with an incidence of 10$30 \%$ [88-90]. Clinical features are related to palsy of the serratus anterior muscle, and the scapula becomes unstable and appears to displace backwards and upwards, leading to neck and upper back pain [91].

The outcomes for seroma formation, blood loss, and the development of wound complications after UD and ES have been systematically reviewed. The conclusion of one review is that UD does not improve outcome [92], compared to ES; in another review there is a 70\% lower risk of axillary seroma formation after surgery with UD than with ES [93], and in axillary dissection, EVS reduces operating time, days of suction drain, and length of hospital stay, without increasing complication rate, compared with conventional ES [94]

\section{Operations in the pelvis}

The sympathetic nerves derive from T10-L2 and form a series of ganglia consisting of the sympathetic chain just medial to the origin of the psoas muscle (Figure 10). The fibers supplying the bladder, rectum, and genital organs have their origin in the T12-L2 nerve roots, and enter the hypogastric plexus below the aortic bifurcation and form two bundles of fibers just medial to the iliac vessels. Damage to the superior hypogastric plexus and the hypogastric nerves causes reduced bladder capacity, and may result in urge incontinence. Clinically bilateral surgical disruption of the inferior hypogastric plexus leads to devastating urinary dysfunction.

The parasympathetic nerves to the pelvis are formed by the second, third and fourth sacral nerve roots as they emerge from the sacral foramina. 


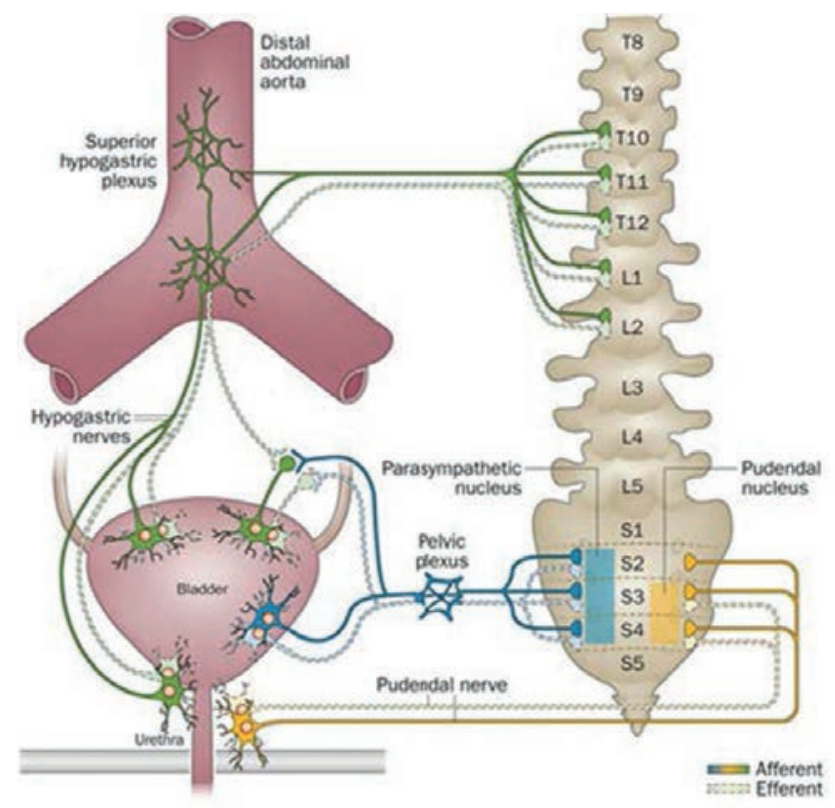

Figure 10: Sacral nerves. Printed with permission.

\section{Radical Prostatectomy}

After radical prostatectomy (RP) for prostate cancer urinary incontinence and erectile dysfunction are the most bothersome sequelae. Radical prostatectomy represents the only treatment for localized prostate cancer with demonstrated benefit on cancer-specific survival, rather than conservative management [95]. A nerve-sparing approach (NS) during the operations has been adopted, which has led to substantial improvements, is a major predictor in erectile function recovery after RP [96]. The association between the NS approach and postoperative urinary continence is still controversial. In some studies attempting neurovascular bundle preservation, the risk of urinary incontinence decreases [97]; however, other studies fail to report such association $[98,99]$. A major contribution is the introduction of the laparoscopic and robot assisted operations with result in better visualization of pelvic 
nerve anatomy [100]. The rate of new onset erectile dysfunction after transurethral resection of the prostate (TURP) using monopolar ES is reported to be as high as $14 \%[101,102]$. Thermal induced nerve injury is implicated as a possible cause.

\section{Rectal Cancer Surgery}

Urinary and sexual dysfunctions are the most recognized complications of rectal resection for carcinoma. The main cause of dysfunction appears to be injury to the autonomic nerves in the pelvis and along the distal aorta (Figure 10). The incidence of genitourinary dysfunction depends on the type of operation performed, and low resections are associated with increased risk of nerve injuries [103]. The occurrence of minor or moderate urinary symptoms early after total mesorektal excision (TME) is up to $35 \%$ [1], and long term bladder dysfunction is around 5\% [3]. Postoperative sexual dysfunction is reported for up to $30 \%$ of patients $[2,104]$.

The use of conventional electric coagulation has been linked to a higher erectile dysfunction rate [105], and therefore the use of coagulation devices during the nerve-sparing steps is debated $[106,107]$.

After rectal cancer operations in women the problem of impaired sexual function was almost completely ignored in surgical literature until the 1980s [108]. Permanent sexual difficulties have been reported in $20 \%$ of female patients and transient problems in a further $12 \%$ of women after intersphincteric rectal excision. However, few studies address the role of neurological damage as a cause of inability to attain orgasm, reduced vaginal sensitivity and vaginal dryness, and these issues remain poorly understood [109]. The cause may be temporary nerve injury caused by traction or diathermy injury, or incomplete division of nerves that later regenerate. 


\section{Aims of the Thesis:}

The overall aim of the thesis was to evaluate the risk of thermal damage with energy based surgical devices.

The specific aims were:

Paper I -to create an animal model for comparing functional impairment and morphological nerve damage with light microscopy after nerve close dissection with ultrasonic dissection and electrosurgery.

Paper II - to compare an ultrasonic dissection, monopolar and bipolar electrosurgery in terms of heat production, nerve function and nerve morphology after in vivo application.

Paper III -to reproduce the animal model in a different laboratory setting and to study the effect on nerve close dissection with electron microscopy after dissection with energy based surgical devices.

Paper IV - to study the use of energy based surgical devices, the risk of complication and operating time with data from a nationwide clinical multicenter quality register. 


\section{Material and methods}

\section{Surgical Procedure Papers I-III}

An animal model in adult Sprague-Dawley rats was used. The range of bodyweight was similar in all experimental groups. Two rats were used as controls. The rats were anaesthetized with ketamine $70 \mathrm{mg}$ per $\mathrm{kg}$ bodyweight and xylazine $5 \mathrm{mg} / \mathrm{kg}$ and maintained on spontaneous ventilation (Papers I and II) or anaesthetized by inhalation of Ethrane with an intraperitoneal injection of $100 \mu \mathrm{l} \mathrm{Nembutal}{ }^{\circledR}(60 \mathrm{mg} / \mathrm{ml})$ per $100 \mathrm{~g}$ of body weight and maintained on spontaneous ventilation (Paper III).

Each sciatic nerve was exposed by separation of the biceps femoris and the tensor fascia lata. The rat's leg was stabilized, and the distances between the nerve and the activated instruments were checked with a microscope and millimeter paper (Figure 11). The instruments, monopolar ES, bipolar ES, US shears and US Focus, were used at settings recommended by the manufacturers. At the end of the procedure, the animals were killed by intracardiac injection of potassium chloride solution.

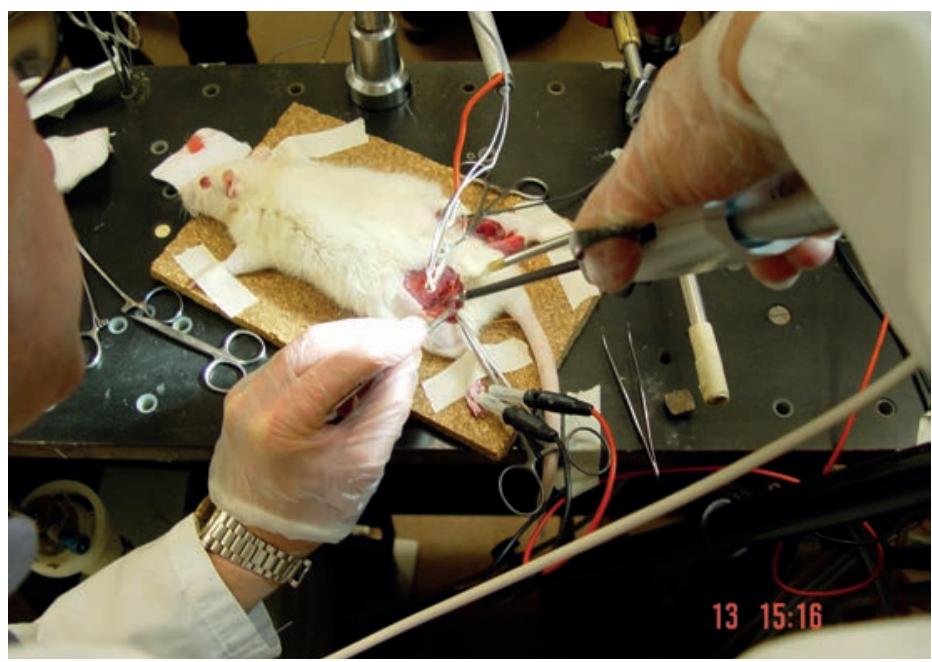

Figure 11: Surgical setup for Paper I-III 


\section{Materials Paper I}

The study involved 37 Sprague-Dawley rats. The biceps femoris muscle was cut in a standard manner just adjacent to the sciatic nerve using monopolar ES, bipolar ES or US shears. Functional experiments $(n=73)$ and morphological examinations $(\mathrm{n}=50)$ of the nerves were conducted. The extent of heat damage was determined in four nerves divided with ES bipolar scissors and five that were divided with UD shears.

\section{Materials Paper II}

The study invlolved 25 Sprague-Dawley rats. Two rats were used as controls. The biceps femoris muscle of anesthetized rats was cut in a standardized longitudinal manner $1 \mathrm{~mm}$ adjacent to the sciatic nerve with UD shears, monopolar ES knife or bipolar ES scissors. Activation time and temperature were recorded continuously within 1-4 mm of the activation site and contralateral to the nerve with two thermoelectric microsensors. Functional experiments $(n=49)$ and morphological examinations $(\mathrm{n}=48)$ of the nerves were conducted.

\section{Material Paper III}

The study involved 40 Sprague-Dawley rats, and was divided into a UD group and a bipolar ES group with 20 animals (40 nerves) in each. Two rats were used as controls. Temperature and EMG $(\mathrm{n}=80)$ were recorded before, during and after activation of the devices. The nerves were examined blinded with light microscope (LM) $(n=40)$ and electronic microscope (EM) $(n=40)$. 


\section{Functional Experiments Papers I-III}

The dissected sciatic nerve was divided proximally and mounted on a pair of silver hook electrodes for stimulation. The motor response was continuously recorded distally by a unipolar stainless steel needle electrode inserted into the foot muscles. Muscle response was measured before and after the surgical procedures through repeated stimulation. Nerve dysfunction was defined as a height reduction of greater than $10 \%$ in the EMG potential evoked after the surgical procedure, compared with that evoked before the procedure (Paper I and II)(Figure 12).

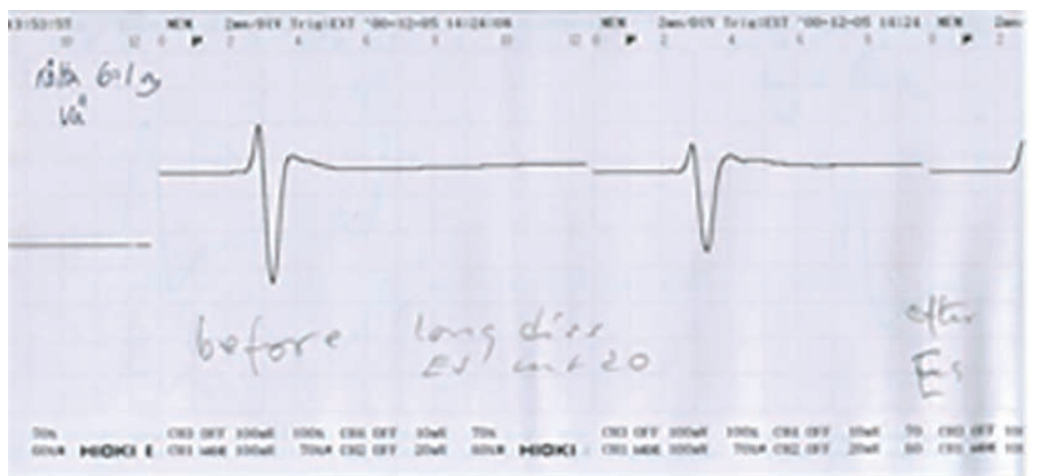

Figure 12: Functional studies; $E M G$ potential before and after the dissection. 


\section{Morphological Studies Papers I-III}

After the functional experiments, nerve tissue was collected for histological and morphological examination. The nerve sections, which were about $10 \mathrm{~mm}$ long, were removed and placed in fixative. The following day, the nerves were embedded in plastic and hardener. After sectioning, the specimens were stained with hematoxylin and eosin. Serial sections were made in distal and proximal directions, starting from the central section of the nerve that had been adjacent to the activated surgical tool. The section with the best technical quality at each location was evaluated and the most severe injury was taken as the result. Nerve tissues were coded and submitted to blind histopathological examination by a pathologist with extensive experience in nerve pathology. The slides were examined with LM (Paper I-III) and EM (Paper III). Nerve injury was classified as: normal, myelin free from vacuoles and no apparent thickening of the myelin sheath; slight injury, small myelin vacuoles and no apparent thickening of the myelin sheath (Figure 13a); moderate injury, obvious vacuolization and swelling with thickening of the myelin sheath, causing encroachment on the axon (Figure 13b); and severe injury, coagulated fibers with markedly thickened, homogeneous and pale myelin sheaths (Figure 13c). This classification has later been referred as the "Carlander classification system".

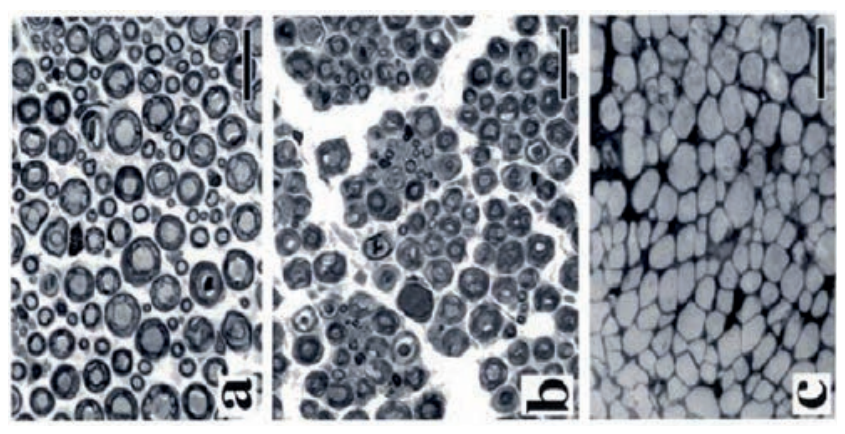

Figure 13: A: Slight nerve fiber damage. Cross-sectioned nerve fibers show minor vacuolization of the myelin. B: Moderate nerve fiber damage with markedly thickened, vacuolated myelin sheaths encroaching on the axons. C: Severely damaged, coagulated nerve fibers. The myelin is maximally swollen, homogeneous and pale. Haematoxylin and eosin stain. Scale bar $20 \mu \mathrm{m}$. 


\section{Temperature Measurements Papers II and III:}

\section{Paper II:}

Temperature spread was measured by thermoelectric sensors designed for an application in tissue. The sensors were based on a thermistor in which electrical resistance was determined (Figure 14). To make a measurement, the tissue was pierced and the sensor was inserted down to the measurement position on each side of the nerve: the distance between the sensors was 3-4 mm. Before being used in the tissue, the temperature sensors were calibrated.

The distance from the blade was set with millimeter paper and a microscope; however, due to tissue movement the actual value could only be exactly determined afterwards by a ruler at each sensor. The temperature was continuously recorded during activation and maximum values were determined after the measurement had been completed, and a computer acquired the data. Temperature rise and time delay of reaching the temperature maximum, as an expression of heat spread within tissue, maximum temperature and thermal dose were measured and calculated.

The thermal dose, the most generally accepted concept for estimating temperature-related tissue damage threshold, was calculated as a product of temperature elevation and duration of exposure at each temperature level through a temperature dependent weighting function [110].
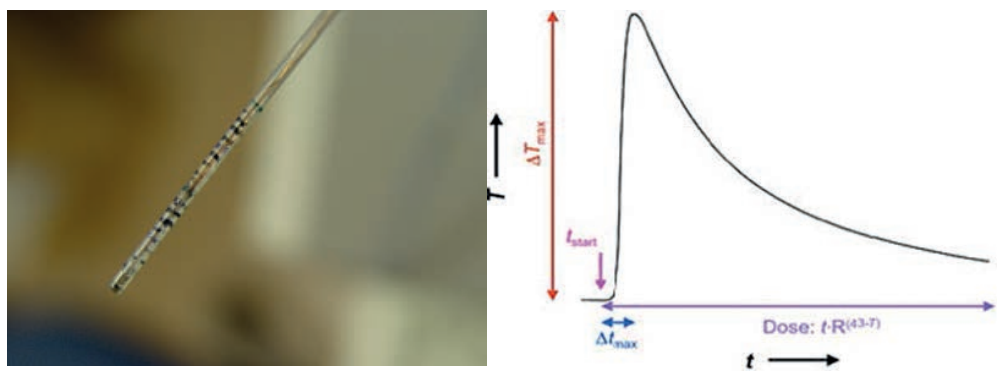

Figure 14: Micro Thermoelectric sensors used in study II and a typical temperature-time curve during the experiments. 


\section{Paper III:}

Temperature was measured by a microprobe. Data were recorded every $0.1 \mathrm{sec}$ during each surgical procedure and analyzed with a computer. The probe was positioned at the sciatic nerve. Measurement started 10 seconds before activation of the device and lasted 10 seconds after the 3-second activation of the EBD.

\section{Paper IV}

For 12 months between 2008 and 2009, the use of EBD devices was prospectively registered in the Scandinavian Quality Register for Thyroid, Parathyroid, and Adrenal Surgery (SQRTPA)(www.thyroidparathyroidsurgery.com). The Register is recognized by the Swedish National Board for Health and Social Welfare. During the study period, the register included 35 clinics in Sweden and covered $88 \%$ of all procedures in the country. Data validity is controlled by a yearly external audit of four participating departments chosen at random. The audit reveals good data quality, with an error of less than 5\%. Participating departments are responsible for compliance with national legislation regulating register participation, including information and acceptance of patients.

\section{Patients:}

1399 consecutive thyroid operations were registered, for 1297 operations, the choice of surgical technique was recorded (C-A-T, bipolar electrosurgery (ES), electronic vessel sealing (EVS), and ultrasonic dissection (UD)), and these patients were selected for this study. Follow-up was after around 6 weeks and 6 months postoperatively. The variables extracted from the registry were: gender, age, diagnosis (Preoperatively); type of operation, choice of surgical instrument, operation time, intraoperative damage to recurrent laryngeal nerve (RLN) and use of topical hemostatic agents (perioperatively); and, treatment with calcium, bleeding with reoperation, postoperative wound infection, and RLN damage noted with indirect laryngoscopy (postoperatively).

The use of per-operative nerve monitoring was not included in the database at the time of the study. 


\section{Statistical Analyzes}

\section{Paper I}

Functional and morphological outcome after ES and ultrasonic dissection were compared with Fisher's exact test. Nerve sections with normal and slight morphological changes were compared with those presenting moderate or severe injury. The extent of heat injury between the UD and ES groups was compared with the Mann-Whitney U non-parametric test.

\section{Paper II}

Group differences were tested as follows. Parameters with almost identical mean values for two of the three groups were combined and tested against the third group with Mann-Whitneys U-test to increase statistical power. The remaining parameters were analyzed with Kruskal-Wallis non-parametric ANOVA, followed by Mann-Whitneys U-test if significance was reached.

\section{Paper III}

Fisher's exact test was used to estimate sample size, and student T-test was used to compare results. All statistical calculations were performed with STATISTICA 8.0.

\section{Paper IV}

The parameters from the register were analyzed with Chi-Square test or Fisher's Exact Test in SAS statistical program (version 9.3 for Windows $7)$. Logistics regression was used to estimate odds ratio (OR) and the 95\% confidence interval.

\section{Overall}

$\mathrm{P}<0.05$ was considered as cut-off for statistical significance in all trials. 


\section{Ethics}

Approval for the studies reported in Papers I and II was obtained from the Regional Ethical Review board at the Hälsouniversitet, Linköping, Sweden (Dnr 2003/64-00). The study and experimentation presented in Paper III, was conducted as guests at the University of Liege, Belgium. Ethical approval was sought and approved by the Animal Ethics Committee, Liege University, Belgium, and the study and experimentation was performed under the approval of the Ministry of Health for experimental animal laboratory. In Paper IV, ethical approval was sought and approved from the Board of SQRTPA, according to this, special ethical permission from each local ethical committee was not necessary.

\section{Conflict of Interests}

The studies included in this thesis were initiated by the authors, and their respective departments supported their participation. The instruments used in Papers I-III were provided by the respective manufacturers (Ethicon Endo Surgery and Valleylab), but the companies had no involvement in the design and conduct of the study, data analysis or preparation of the manuscript. The studies were arranged on the basis of a written contract, prior to the studies and independent of the manufacturers of the tested surgical instruments. 


\section{Results}

\section{Paper I}

\section{Electrophysiological Measurements}

The measurement of EMG potentials from a perpendicular dissection revealed more nerves were damaged in the bipolar ES group than in the UD group, but this was not statistically significant (Table 1). However, fewer nerves were impaired after longitudinal UD than with monopolar ES $(P=0.004)$, but there was no difference between UD and bipolar ES.

Nerve injury after perpendicular cut

Monopolar ES

Bipolar ES US shears
5 of 17

2 of 17
Nerve injury after longitudinal cut

Table 1: EMG findings Paper I. ${ }^{\star} P<0.05$, between Monopolar ES and UD.

\section{Microscopic Assessments}

There was more nerve fiber damage after bipolar ES compared to UD, both after perpendicular- $(\mathrm{P}=0.006)$ and longitudinal cut $(\mathrm{P}=0.024)$ (Table 2). In the experiment investigating the extent of heat injury, the length of damage was greater with bipolar ES (median $1782 \mu \mathrm{m}$ (range 1584-2128)) than with UD (median $990 \mu \mathrm{m}$ (range 94-1138: $\mathrm{P}=$ 0.016)). Normal morphology was seen in the control nerves. 


\begin{tabular}{|ccccccc} 
& \multicolumn{2}{c}{ Perpendicular } & & \multicolumn{3}{c}{ Longitudinal } \\
\cline { 2 - 3 } & $\begin{array}{c}\text { Bipolar } \\
\text { ES }\end{array}$ & $\begin{array}{c}\text { US } \\
\text { shears }\end{array}$ & $\begin{array}{c}\text { Monopolar } \\
\text { ES }\end{array}$ & $\begin{array}{c}\text { Bipolar } \\
\text { ES }\end{array}$ & $\begin{array}{c}\text { US } \\
\text { shears }\end{array}$ \\
\hline $\begin{array}{c}\text { Normal : slight } \\
\text { damage }\end{array}$ & $1: 3$ & $4: 6$ & & $0: 3$ & $0: 1$ & $3: 3$ \\
$\begin{array}{c}\text { Moderate : severe } \\
\text { damage }\end{array}$ & $4: 2$ & $1: 0$ & & $3: 4$ & $7: 3$ & $2: 0$ \\
$P^{*}$ & 0.024 & & 0.150 & 0.006 & \\
\end{tabular}

Table 2: Microscopic findings Paper I. ${ }^{\star} P<0.05$.

\section{Paper II}

\section{Temperature Measurements}

The maximum temperature elevation $(\mathrm{p}=0.024)$ and thermal dose $(\mathrm{p}=0.049)$ was higher for bipolar ES than for the UD instrument (Fig 15). The time delay, the time it took for reaching max temperature, was higher for UD than for Bipolar and Monopolar ES ( $p=0.006, p=0.015)$ (Table 3). Monopolar ES induced lower maximum temperatures and thermal dose values, but the results varied and were not statistically significant over the whole range.

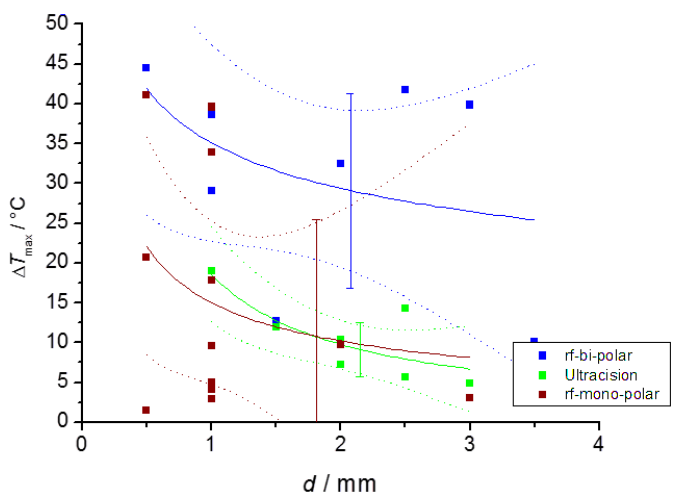

Figure 15: Max temperature to distance. Blue= Bipolar ES, Green $=U D$, Red $=$ Monopolar ES. The dashed lines give the $90 \%$ confidence ranges. 


\section{Electrophysiological Measurements}

The EMG potential measurements after dissection close to the nerve revealed loss was generally infrequent in all groups and were least common in the US group, without being significant, than in both bipolar $(\mathrm{p}=0.11)$ and monopolar ES groups $(\mathrm{p}=0.10$ : Table 3$)$.

\begin{tabular}{|c|c|c|c|c|c|c|c|}
\hline & $\begin{array}{l}\text { Monopolar- } \\
\text { ES (n=18) }\end{array}$ & $\begin{array}{c}\text { Bipolar-ES } \\
\quad(n=16)\end{array}$ & $\begin{array}{c}\text { UD } \\
(n=15)\end{array}$ & P* & $\mathrm{P}^{* *}$ & $\mathrm{P}^{* * *}$ & $\mathrm{P} * * * *$ \\
\hline Max temp & $\begin{array}{c}38,9 \\
(32,1-69,7)\end{array}$ & $\begin{array}{c}55,6 \\
(35,9-73,6)\end{array}$ & $\begin{array}{c}39,6 \\
(29,0-61,2\end{array}$ & 0,007 & 0,597 & 0,041 & 0,064 \\
\hline $\begin{array}{l}\text { Max temp } \\
\text { elevation }\end{array}$ & $\begin{array}{c}9,1 \\
(1,5-41,1)\end{array}$ & $\begin{array}{c}26,8 \\
(3,8-44,6)\end{array}$ & $\begin{array}{c}12,0 \\
(1,4-31,7)\end{array}$ & 0,032 & 0,022 & 0,762 & 0,024 \\
\hline $\begin{array}{c}\text { Thermal } \\
\text { dose }\end{array}$ & $\begin{array}{c}-1,0 \\
(-8,5-18,7)\end{array}$ & $\begin{array}{c}8,2 \\
(-5,7-21,2)\end{array}$ & $\begin{array}{c}1,1 \\
(-8,7-13,1)\end{array}$ & 0,030 & 0,014 & 0,509 & 0,049 \\
\hline Time delay & $\begin{array}{c}9,4 \\
(-9,4-34,5)\end{array}$ & $\begin{array}{c}11,7 \\
(5,1-62,9)\end{array}$ & $\begin{array}{c}20,3 \\
(13,7-87,6)\end{array}$ & 0,009 & 0,297 & 0,006 & 0,015 \\
\hline $\begin{array}{c}\text { EMG- } \\
\text { potential }\end{array}$ & $60,6(47,6)$ & $\begin{array}{c}62,5 \\
(47,8)\end{array}$ & $\begin{array}{c}88,7 \\
(28,0)\end{array}$ & 0,188 & & & \\
\hline $\begin{array}{c}\text { Morphology } \\
\%\end{array}$ & $\begin{array}{c}39,2 \\
(10,0-56,7)\end{array}$ & $\begin{array}{c}42,5 \\
(4-86,7)\end{array}$ & $\begin{array}{c}32,5(0,0- \\
63,3)\end{array}$ & 0,077 & 0,597 & 0,041 & 0,064 \\
\hline
\end{tabular}

Table 3: Results Paper III ( ${ }^{*} p$ : Kruskal-Wallis ANOVA by ranks, ${ }^{* *}$ : MannWhitney U-test: Monopolar ES vs Bipolar ES, ${ }^{* *}{ }^{*}$ : Mann-Whitney U-test: Monopolar ES vs US, ${ }^{* * *}$ p: Mann-Whitney U-test: Bipolar ES vs US)

\section{Handheld Experiments}

In all measurements, $100 \%$ nerve potential was recorded, except in one case where $0 \%$ was measured; this case had the highest dose $\left(5 \times 10^{5}\right.$ $\mathrm{min}$ ) and the highest maximum temperature elevation. However, one experiment with a slightly less dose $\left(3.3 \times 10^{5} \mathrm{~min}\right)$ yielded full nerve potential. Several experiments in the range of $1 \times 10^{3} \mathrm{~min}$ to $1 \times 10^{4} \mathrm{~min}$ also had full nerve potential.

\section{Microscopic Assessments}

Moderate and severe morphological damage was less common in the UD group than in the monopolar ES group ( $\mathrm{p}=0.041$ : Table 3 ). Normal morphology was present in the control nerves. 


\section{Paper III}

\section{Temperature measurements}

Before activation of the EBD, almost similar temperatures were measured in both groups (Bipolar ES: $27.1^{\circ} \mathrm{C}$ and UD: $26.8^{\circ} \mathrm{C}$ ). The maximum and mean temperatures recorded during the procedures were higher in the Bipolar ES group than in the UD group (Table 4). The residual temperature recorded 10 seconds after EBD activation period was also higher in the Bipolar ES group. Excitation time, the period between the $10 \%$ point of maximum temperature elevation and $90 \%$ during which the temperature increased, was higher for Bipolar ES than for UD. The average steepness of the temperature increase per second during activation of EBD was steeper for the Bipolar ES group than for the UD group (Table 4).

\begin{tabular}{|c|c|c|c|c|c|}
\hline & $\begin{array}{l}\text { Bipolar } \\
\text { ES }\end{array}$ & SD & UD & SD & P-value \\
\hline $\mathrm{T}^{\circ} \operatorname{Max}\left(\mathrm{C}^{\circ}\right)$ & 39.6 & 7.5 & 35.6 & 5.09 & $0.006^{*}$ \\
\hline $\begin{array}{c}\text { Mean } t^{\circ}\left(23^{\prime}\right) \\
\left(C^{\circ}\right)\end{array}$ & 34 & 3.7 & 31 & 2.6 & $0.00003^{*}$ \\
\hline $\begin{array}{l}T^{\circ} \text { after } \\
10^{\prime}\left(C^{\circ}\right)\end{array}$ & 35.9 & 4.1 & 32 & 3.2 & $0.0000^{*}$ \\
\hline $\begin{array}{l}\text { Excitation } \\
\text { time (s) }\end{array}$ & 8.05 & 4.9 & 6.19 & 3.2 & $0.046^{*}$ \\
\hline $\begin{array}{c}\text { Average } \\
\text { steepness } \\
\text { of } \mathrm{T}^{\circ} / \mathrm{sec}\end{array}$ & 3.09 & 5.5 & 2.16 & 3.1 & 0.3 \\
\hline
\end{tabular}

Table 4: Temperature results Paper III.

\section{Electrophysiological Measurements}

After instrument activation, EMG amplitude decreased by $3 \%$ in the UD group and 6\% in the bipolar ES group, although this was not significant. 
However, within the same group, the difference in amplitude before and after EBD activation was significantly lower in the Bipolar ES group but not in the UD group.

\section{Microscopic Assessments}

Due to the slight hyperosmolarity of the fixative, the fascicules were ovoid or reniform in shape, and occasionally, large myelinated axons presented axonal retraction and myelin irregularities in the form of axonal out pouching. However, such features are routinely seen in biopsies of normal nerves and have no pathological importance [111]. The lesions after the disections were mild in severity and involved the myelin sheath of myelinated fibers. Both myelinated and unmyelinated fibers had normal axon morphology (Figure 16). Clinically important lesions occurred in the sciatic nerve of 4/21 rats in the Bipolar ES group and $2 / 19$ rats in the UD group, but without statistical significance. Normal morphology was present in the control nerves.

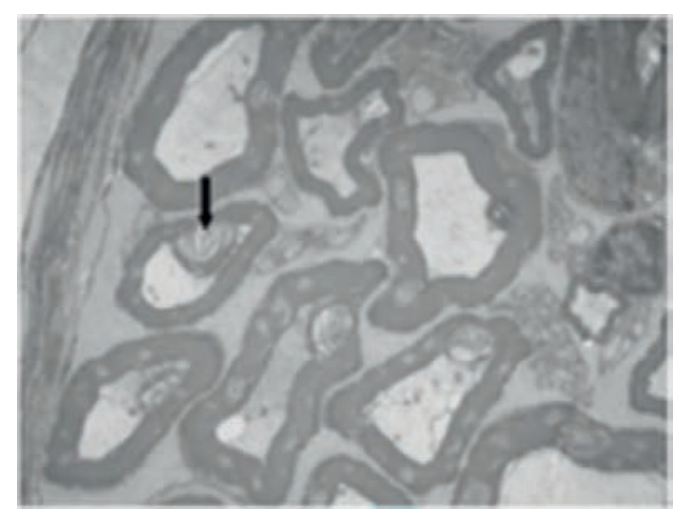

Figure 16: Electron Microscopy. Protrusions of the myelin sheath into the axon (arrow), patchy loss of density in the sheath and dilatations of the SchmidtLanterman incisures. Detachment of the sheath from the axon. 


\section{Paper IV}

\section{Preoperative parameters}

1399 thyroid operations were registered between May 2008 and May 2009. For 102 cases, the choice of surgical instrument was not recorded; therefore, these cases were excluded. The groups of surgical instruments did not differ in relation to clinical variables: C-A-T was used in $16.6 \%$ of the operations, bipolar ES in 56.6\%, EVS in $12.3 \%$, and UD in $14.6 \%$. The mean surgical time was shortest in the UD group and longest in the EVS group. Results are presented in Table 5.

\begin{tabular}{|c|c|c|c|c|c|}
\hline & $\begin{array}{l}\text { Clamp and } \\
\text { tie }(n=215)\end{array}$ & $\begin{array}{c}\text { Bipolar ES } \\
(\mathrm{n}=734)\end{array}$ & $\begin{array}{c}\text { Electric } \\
\text { vessel sealing } \\
(n=159)\end{array}$ & $\begin{array}{c}\text { Oltrasonic } \\
\text { Dissection } \\
(n=189)\end{array}$ & $\begin{array}{c}\text { Total } \\
(n=1297)\end{array}$ \\
\hline Female (\%) & $162(75.4)$ & $603(82.2)$ & $124(78)$ & $150(79.4)$ & $1039(80.1)$ \\
\hline Male (\%) & $53(24.6)$ & $131(17.8)$ & $35(22)$ & $39(20.6)$ & $258(19.9)$ \\
\hline $\begin{array}{l}\text { Age Mean } \\
\text { (SD) } \\
\text { Range }\end{array}$ & $\begin{array}{c}49.1(15.6) \\
(10-83)\end{array}$ & $\begin{array}{c}49.6(16.3) \\
(13-94)\end{array}$ & $\begin{array}{c}48.2(15.6) \\
(17-94)\end{array}$ & $\begin{array}{c}50.4(15.7) \\
(14-82)\end{array}$ & $\begin{array}{c}49.5(16.03) \\
(10-94)\end{array}$ \\
\hline $\begin{array}{l}\text { Gland weight } \\
\text { (g) } \\
\text { Mean (SD) } \\
\text { Range }\end{array}$ & $\begin{array}{c}68.7(116.5) \\
(0.3-390)\end{array}$ & $\begin{array}{c}63.8(66.0) \\
(0.2-390)\end{array}$ & $\begin{array}{c}64.4(63.1) \\
(6.8-302)\end{array}$ & $\begin{array}{c}75.1(69.2) \\
(5.7-355)\end{array}$ & $\begin{array}{c}66.4(76.1) \\
(0.2-390)\end{array}$ \\
\hline $\begin{array}{l}\text { Operation } \\
\text { time (min) }\end{array}$ & & & & & \\
\hline $\begin{array}{c}\text { Mean (SD) } \\
\text { Range }\end{array}$ & $\begin{array}{c}122.9(43.7) \\
(42-345)\end{array}$ & $\begin{array}{c}130.6 *(62.7) \\
(34-620)\end{array}$ & $\begin{array}{c}162.6^{* * *} \\
(101.4) \\
(44-480)\end{array}$ & $\begin{array}{c}111.2 * * \\
(37.6) \\
(25-240)\end{array}$ & $\begin{array}{c}130.4(62.3) \\
(25-620)\end{array}$ \\
\hline $\begin{array}{l}\text { Topical } \\
\text { Hemostatic } \\
\text { agent }\end{array}$ & $\begin{array}{l}69 / 215 \\
(32.1 \%)\end{array}$ & $\begin{array}{l}382 / 734 \\
(52.0 \%)\end{array}$ & $\begin{array}{l}126 / 159 \\
(79.2 \%)\end{array}$ & $\begin{array}{l}88 / 189 \\
(46.6 \%)\end{array}$ & $\begin{array}{c}665 / 1297 \\
(51.2 \%)\end{array}$ \\
\hline
\end{tabular}

Table 5: Preoperative and Perioperative parameters Paper IV $\left({ }^{*} p<0.05,{ }^{*} p<0.01\right.$, $\left.{ }^{* * *} p<0.001\right)$. 


\section{Postoperative Hypoparathyroidism}

At discharge, $27.9 \%$ of patients were medicated with calcium: $21.1 \%$ in the C-A-T group, $34.5 \%$ in the bipolar ES group, $28.3 \%$ in the EVS group, and $15.4 \%$ in the UD group (Table 6). At discharge, the odds ratio (OR) for treatment with calcium was 2.91 times higher for the Bipolar ES group and 2.17 times higher for EVS group than for the UD group: this risk was also higher in the bipolar ES group than the C-A-T group (Table 7). After 6 weeks, $14.0 \%$ of the patients were on supplementation due to hypocalcemic symptoms: $12.7 \%$ of the C-A-T group, $17.1 \%$ of bipolar ES, $14.1 \%$ of EVS, and $6.3 \%$ of the UD group (Table 6). After 6 weeks, the OR of treatment with calcium was 3.62 times higher for the bipolar group and 3.37 times higher for EVS group than for the UD group (Table 7). After 6 months, treatment due to hypocalcemic symptoms was reported in 5.9\% of patients: $3.8 \%$ in the C-A-T group, $7.6 \%$ in the bipolar ES, $6.2 \%$ in the EVS group, and $2.7 \%$ in the UD group. The statistical differences in the need for calcium treatment disappeared at 6 months.

\section{Postoperative RLN Injury}

There were 1943 nerves at risk. At six weeks follow-up 48 RLN injuries were reported (2.5\%). The OR for RLN injury in the bipolar ES group increased by 1.73 , compared to the C-A-T group, although this was not statistically significant (Table 6). RLN injury after 6 months was reported in 14 patients and 16 nerves were injured (0.89\%). Results are presented in Table 6 and Table 7.

\section{Locally applied hemostatic agents}

Tachosil, Surgicel, and Collagen fleece were used in 665 (51.2\%) of the operations: Tachosil, the most expensive hemostatic agent, was used in 376 of these 665 operations. The use of hemostatic agents was higher in the bipolar ES (52.0\%), EVS (79.2\%) and UD (46.6\%) groups than in 
the C-A-T group (32.1\%). Results are presented in Table 5 and Table 7. In the multivariate analyzes (adjusted for age, gender, type of operation, operation time, and gland weight), bipolar ES, EVS, UD, and gland weight $>100$ gram were risk factors for the use of a hemostatic agents.

\begin{tabular}{|c|c|c|c|c|c|}
\hline & Clamp and tie & Bipolar ES & $\begin{array}{c}\text { Electric vessel } \\
\text { sealing }\end{array}$ & $\begin{array}{l}\text { Ultrasonic } \\
\text { Dissection }\end{array}$ & Total \\
\hline $\begin{array}{l}\text { Calcium } \\
\text { treatment at } \\
\text { discharge }\end{array}$ & $\begin{array}{c}19 / 90 \\
(21.1 \%)\end{array}$ & $\begin{array}{l}108 / 313 \\
(34.5 \%)\end{array}$ & $\begin{array}{c}28 / 99 \\
(28.3 \%)\end{array}$ & $\begin{array}{l}18 / 117 \\
(15.4 \%)\end{array}$ & $\begin{array}{l}173 / 619 \\
(27.9 \%)\end{array}$ \\
\hline $\begin{array}{l}\text { Calcium } \\
\text { treatment at } \\
6 \text { weeks } \\
\text { postop }\end{array}$ & $\begin{array}{c}10 / 79 \\
(12.7 \%)\end{array}$ & $\begin{array}{l}53 / 310 \\
(17.1 \%)\end{array}$ & $\begin{array}{c}14 / 99 \\
(14.1 \%)\end{array}$ & $\begin{array}{l}7 / 111 \\
(6.3 \%)\end{array}$ & $\begin{array}{l}84 / 599 \\
(14.0 \%)\end{array}$ \\
\hline $\begin{array}{l}\text { Calcium } \\
\text { treatment at } \\
6 \text { months } \\
\text { postop }\end{array}$ & $\begin{array}{c}3 / 79 \\
(3.8 \%)\end{array}$ & $\begin{array}{c}23 / 302 \\
(7.6 \%)\end{array}$ & $\begin{array}{c}6 / 97 \\
(6.2 \%)\end{array}$ & $\begin{array}{l}3 / 112 \\
(2.7 \%)\end{array}$ & $\begin{array}{l}35 / 590 \\
(5.9 \%)\end{array}$ \\
\hline $\begin{array}{l}\text { Peroperative } \\
\text { RLN injury }\end{array}$ & $\begin{array}{c}1 / 311 \\
(0.32 \%)\end{array}$ & $\begin{array}{c}15 / 1061 \\
(1.4 \%)\end{array}$ & $\begin{array}{c}1 / 261 \\
(0.38 \%)\end{array}$ & $\begin{array}{c}1 / 310 \\
(0.32 \%)\end{array}$ & $\begin{array}{l}18 / 1943 \\
(0.94 \%)\end{array}$ \\
\hline $\begin{array}{l}\text { RLN palsy } 6 \\
\text { weeks postop }\end{array}$ & $\begin{array}{l}5 / 294 \\
(1.7 \%)\end{array}$ & $\begin{array}{c}32 / 1042 \\
(3.1 \%)\end{array}$ & $\begin{array}{l}6 / 256 \\
(2.3 \%)\end{array}$ & $\begin{array}{l}5 / 306 \\
(1.6 \%)\end{array}$ & $\begin{array}{c}48 / 1898 \\
(2.5 \%)\end{array}$ \\
\hline $\begin{array}{l}\text { RLN palsy } \\
6 \text { months } \\
\text { postop }\end{array}$ & $\begin{array}{c}1 / 292 \\
(0.34 \%)\end{array}$ & $\begin{array}{c}12 / 1041 \\
(1.2 \%)\end{array}$ & $\begin{array}{l}0 / 159 \\
(0 \%)\end{array}$ & $\begin{array}{l}3 / 304 \\
(1.0 \%)\end{array}$ & $\begin{array}{l}16 / 1796 \\
(0.89 \%)\end{array}$ \\
\hline $\begin{array}{l}\text { Reoperation } \\
\text { for } \\
\text { heamtoma }\end{array}$ & $\begin{array}{l}5 / 215 \\
(2.3 \%)\end{array}$ & $\begin{array}{c}10 / 734 \\
(1.4 \%)\end{array}$ & $\begin{array}{l}3 / 159 \\
(1.9 \%)\end{array}$ & $\begin{array}{l}5 / 189 \\
(2.6 \%)\end{array}$ & $\begin{array}{c}23 / 1297 \\
(1.8 \%)\end{array}$ \\
\hline
\end{tabular}

Table 6: Postoperative parameters Paper IV.

\begin{tabular}{|c|c|c|c|c|c|c|c|}
\hline & $\begin{array}{c}\text { Ca- } \\
\text { disharge }\end{array}$ & $\begin{array}{l}\mathrm{Ca}- \\
6 \mathrm{w}\end{array}$ & $\begin{array}{l}\mathrm{Ca}- \\
6 \mathrm{~m}\end{array}$ & $\begin{array}{l}\text { RLN- } \\
6 \mathrm{w}\end{array}$ & $\begin{array}{l}\text { Rebleeding } \\
\text { with } \\
\text { operation }\end{array}$ & $\begin{array}{l}\text { Hemostatic } \\
\text { topical } \\
\text { agent }\end{array}$ & $\begin{array}{c}\text { Operation } \\
\text { time } \\
\text { (min) }\end{array}$ \\
\hline$N$ & 640 & 599 & 589 & 1898 & 1297 & 1297 & \\
\hline $\begin{array}{l}\text { Bip ES- } \\
\text { C.A.T }\end{array}$ & $\begin{array}{c}2.01 \\
(1.14- \\
3.50)^{*}\end{array}$ & $\begin{array}{c}1.44 \\
(1.1-2.99)^{*}\end{array}$ & $\begin{array}{l}6.45 \\
(0.86 \\
48.54)\end{array}$ & $\begin{array}{c}1.73 \\
(0.57-5.26)\end{array}$ & $\begin{array}{c}0.58 \\
(0.2-1.72)\end{array}$ & $\begin{array}{c}2.74 \\
(1.97-3.81)^{*}\end{array}$ & $\begin{array}{c}2.05 \\
(5.76-9.85)\end{array}$ \\
\hline EVS - C-A.T & $\begin{array}{c}1.49 \\
(0.77-2.92)\end{array}$ & $\begin{array}{c}1.35 \\
(0.58-3.16)\end{array}$ & $\begin{array}{l}5.14 \\
(0.61 \\
43.65)\end{array}$ & $\begin{array}{c}1.41 \\
(0.38-5.27)\end{array}$ & $\begin{array}{c}0.81 \\
(0.19-3.43)\end{array}$ & $\begin{array}{c}9.28 \\
(5.74-15.74)^{*}\end{array}$ & $\begin{array}{l}22.60 \\
(2.86 \\
42.30)^{\circ}\end{array}$ \\
\hline$U D=C \cdot A \cdot T$ & $\begin{array}{c}0.69 \\
(0.34-1.41)\end{array}$ & $\begin{array}{c}0.40 \\
(0.14-1.15)\end{array}$ & $\begin{array}{l}2.15 \\
(0.22 \\
21.02)\end{array}$ & $\begin{array}{c}1.17 \\
(0.29-4.75)\end{array}$ & $\begin{array}{c}1,14 \\
(0.33-4.0)\end{array}$ & $\begin{array}{c}2.20 \\
(1.46-3.32)^{*}\end{array}$ & $\begin{array}{c}-25.5 \\
(-33.21= \\
17.78)^{*}\end{array}$ \\
\hline Bip ES -EVS & $\begin{array}{c}1.34 \\
(0.81-2.2)\end{array}$ & $\begin{array}{c}1.07 \\
(0.58-1.98)\end{array}$ & $\begin{array}{c}1.25 \\
(0,49-3.8)\end{array}$ & $\begin{array}{c}1.23 \\
(0.51-2.99)\end{array}$ & $\begin{array}{c}0.72 \\
(0.19-2.64)\end{array}$ & $\begin{array}{c}0.34 \\
(0.20-0.60)\end{array}$ & $\begin{array}{l}-20.55 \\
(-39.9 . \\
1.14)^{*}\end{array}$ \\
\hline Bip ES-UD & $\begin{array}{c}2.91 \\
(1.67-5.06)^{*}\end{array}$ & $\begin{array}{c}3.62 \\
(1.51-8.68)^{*}\end{array}$ & $\begin{array}{l}3.01 \\
(0,89 \\
10.22)\end{array}$ & $\begin{array}{c}1.48 \\
(0.54-4.04)\end{array}$ & $\begin{array}{c}0.50 \\
(0.17 \cdot 1.5)\end{array}$ & $\begin{array}{c}1.28 \\
(0.89-1.88)\end{array}$ & $\begin{array}{l}27.74 \\
(20.43 . \\
34.61)^{*}\end{array}$ \\
\hline EVS-UD & $\begin{array}{c}2.17 \\
(1.11-4.22)^{*}\end{array}$ & $\begin{array}{c}3.37 \\
(1.26-9.0)^{*}\end{array}$ & $\stackrel{2.4}{(0.58-9.85)}$ & $\begin{array}{c}1.2 \\
(0.35-4.12)\end{array}$ & $\begin{array}{c}0.71 \\
(0.17-3.01)\end{array}$ & $\begin{array}{c}4.21 \\
(2.62-6.78)^{*}\end{array}$ & $\begin{array}{l}48.10 \\
(28.47 . \\
67.71)^{*}\end{array}$ \\
\hline
\end{tabular}

Table 7: Postoperative results Paper IV. Odds ratios adjusted for age, gender, type of operation, operation time, and gland weight. 


\section{Discussion}

The overall aim of the thesis was to evaluate the risk of collateral thermal damage with energy based surgical devices.

In summary, the experiments showed that the physical properties of UD and ES differ and generate different nerve tissue responses according to nerve functional tests and microscopic assessment (Paper I-III). The physical properties of the EBD may also explain different clinical outcomes (Paper IV).

There are limitations in the literature regarding the evaluation of EBD.

- Technology progressively advances; therefore, the EBD in published studies are "old" at publication, as newer generations have evolved.

- Methodology is seldom standardized.

- Surgical experience is seldom stated, nor whether this experience is equally distributed among the groups.

- There is sponsorship bias. Relevant RCTs are sponsored [68, 112-115], and negative findings from such trials may not have been published [116]. This may be of particular relevance when comparing surgical technologies designed by different manufacturers.

- Traditional meta-analyses have several limitations [117], including the inability to compare more than two interventions simultaneously, and in calculating the relative efficacy of two or more interventions if they have not been directly compared within a trial [118].

Surgeon's knowledge about EBDs can be improved. In a study by Feldman et al [11], $31 \%$ of experienced surgeons could not identify 
the device least likely to interfere with a pacemaker; $13 \%$ did not know that thermal injury can extend beyond the jaws of a bipolar instrument; and $10 \%$ considered a dispersive pad should be cut to fit a child. Furthermore, baseline knowledge appeared to be similar to those of junior surgical residents.

In many cases, post-operative complications after surgery lead to chronic medication and disability. These complications are not only important for the individual patient, but also have a socioeconomic impact. Thus increased knowledge about the EBDs could reduce morbidity and mortality.

\section{Animal Model}

Animal models are a fundamental tool in life sciences. A serious assessment of the models used is necessary to draw conclusions and make decisions in an evidence-based manner. No model is perfect and includes choices. The term "model" implies deviation from reality, usually by simplifying and reducing variables.

The aim was to study heat propagation from the EBD through the tissue, and if this led to functional impairment of the nerve EMG and morphological nerve damage. As a first step an in vivo animal model for studying the tissue effect from different EBDs -with special reference to nerve injury was developed. Paper I and II were in collaboration with a laboratory with long experience in, and the equipment for neurophysiology studies. In Paper III, the same model was used in a laboratory in Liege, Belgium.

The model on anesthetized rats allowed standardized testing. During the experiments, millimeter paper and set incisions times, for each device, rendered the incisions as precise as possible, in order to make viable comparisons between the EBD. Functional impairment of the nerve was evaluated by the EMG potential and the sciatic nerve was divided proximally to avoid reentry-signals from the spinal cord. 
In vivo tissue have different characteristics from in vitro tissue, most importantly, blood perfusion can modify thermal spread [119]. Many studies use an in vitro setup $[14,16,120,121]$. However, in vitro studies may not be fully relevant to clinical applications, as the locally produced heat will be transported by the circulating blood and electric conductivity is different from living tissue. In addition, they are often carried out at lower temperatures than occur in normal body tissues.

After the experiments the nerves were collected for blinded microscopic evaluation. The classification of neural thermal damage we used in the first two papers was developed by our collaborator dr Nordborg. This has later been described as "the Carlander classification system" [122, 123].

\section{Nerve Injuries from EBD}

Despite the daily use of EBD, surgeons may not always be familiar with their basic principles and functions [124], which leads to the risk of iatrogenic nerve injuries. Although nerve protection and nerve-sparing surgery is discussed $[78,104,125]$, the different EBDs characteristics are rarely tested.

In the experimental setup, Ultrasonic dissection caused less trauma to adjacent nerve fibers than electrosurgery (Paper I). Both the functional tests and morphological results suggested UD might be safer than ES for dissection close to nerves. Moderate and severe morphological damage was less common with UD than with monopolar ES and bipolar ES (Paper II), and the EMG potential were lower with Bipolar ES than with UD (Paper III). Only a few clinically important damages in the myelin sheath were observed with EM. The lesions detected were more common in the Bipolar ES group.

These results were in agreement with other studies concluding UD creates less tissue trauma and inflammation than ES $[126,127]$. A comparison beween UD and ES has been made at the molecular level, by 
studying gene transcript expression and protein levels after subcutaneous incisions in pig [128]. UD produced fewer differentially expressed genes and proteins than ES, especially those involved in the inflammatory mediation. However, in a study of EBD on rabbits [61], there is histological evidence UD causes a greater inflammatory response than EVS. However the tissue response after UD was less than after both monopolar and bipolar ES.

In a similar study, by Chen et al [129], UD near rat sciatic nerve resulted in lower incidence of neural impairment, and less inflammation suggesting recovery from nerve damage would take shorter time after ultrasonic dissection than with monopolar ES. The same group investigated [130] whether the nerve injury extended beyond the acute period through EMG evaluations immediately, after 3 hours and after 7 days, and concluded ES causes lower EMG potential both in the acute period and the subacute phase and UD is comparable to sham surgery. However they gave pancuronium to the animals making the EMG results difficult to interpret.

In the clinical setting, the incidence of RLN palsy after 6 weeks was 2.5\% (48 patients)(Paper IV). Despite being a large study (nerves at risk=1943), the statistical power was too low to be able to disentangle the effects of different EBDs. We could therefore not draw any conclusions about the clinical effects in nerves. After 6 months most of the observed nerve impairments had resolved and only $0.89 \%$ of the patients showed any sigh of RLN palsy. 


\section{Thermal Spread by EBD}

Papers II and III focused on collateral thermal spread. The lateral temperature values and thermal doses in the tissues strongly depended on the distance to the blade and the time of EBD exposure; this is in accordance with another study on temperature spread [82]. Advanced micro thermometers measured the temperature and the thermal dose of monopolar ES, bipolar ES, and UD in nerves close to dissection. Bipolar ES generated the highest temperatures and highest thermal doses and had a greater variation in values than the UD. The smaller statistical confidence intervals for thermal spread with UD, may be important in clinical settings, where surgeons expect the same results each time the EBD is activated. As there is a lack of studies in this area, the results from measuring thermal doses in transected tissue (Paper II) may be clinically relevant, and these results (Paper I-III) are corroborated by Garas et al [15], who report that the lateral thermal spread of UD is approximately 1-3 mm, which is half of the spread with bipolar systems.

Tissue effects from EBD do not just depend on activation time, ESU settings, and thermal causes, the passing of the electric current could be part of the neurological trauma [129]. As physical principles behind UD and ES are different, the mode of tissue heating (mechanical vs electrical) could be as critical to iatrogenic damage as the temperature reached by the EBD. The damage to adjacent tissue is not directly related to the temperature of the blade, but depends on the energy mode and application time [121] [16].

Large differences are reported in thermal spread of EBDs, ranging from a few millimeters [34, 119, 121, 131] to one $\mathrm{cm}$ or more [132]. This disparity in values highlights the difficulty in defining safety distances for EBDs, as safety in surgery is much more, than just what kind of EBD the surgeon uses during the operation. Important safety factors include level of experience of the surgeon, type of transected tissue and knowledge about the EBDs.

The EBDs producing the highest temperatures and thermal doses during the experimental dissections (Paper I-III) also had the highest 
incidences of hypocalcemia (Paper IV). The risk was up to nearly 4 times higher within the Bipolar ES group, compared to the UD-group. Although a thermocamera was used to record superficial thermal spread during the dissections (Paper II), these values proved to be uncertain and did not correlate to the exact tissue values generated with the microsensors for in vivo tissue. Therefore, these data were excluded from the results.

\section{Clinical Findings}

Due to the high vascularization of the thyroid gland EBDs are increasingly used during thyroid surgery, and are probably studied mostly in this surgical field. Prospective studies indicate reduced operative times and costs for thyroidectomies when EBDs are used rather than C-A-T $[112,133,134]$.

In RCT comparisons of UD and EVS in thyroid surgery reveal no difference in postoperative morbidity $[135,136]$, but shorter operating times with UD. In some RCT $[137,138]$, EVS has shorter operating times with $15-40 \%$ gain ranges, than traditional C-A-T, and UD is the most time efficient hemostatic, followed by EVS and C-A-T[15, 18].

In our nationwide multicenter register study (Paper IV), there was a reduction in duration of surgery with UD compared to bipolar ES, EVS, and C-A-T. With EVS, the mean operating time was of 51 minutes longer compared to UD and this was still significant after adjustment for type of operation, gland weight, age, and gender. However, further studies are required to confirm whether surgical time saving with EBD can translate into global cost savings.

Reduction in operating time is a benefit for surgical practice; however, the saving in operation time has to be offset with higher material costs and the risk of heat-generated complications. For example in thyroidectomy, the cost for EBDs accounts for a substantial proportion of the total procedure cost (15-20\%) [114, 137]. 
Locally applied haemostatic agents (Tachosil, Floseal and Collagen fleece) were used in $51.2 \%$ of the operations, with higher usage in the EBD group, and there was an increased odds ratio for of the use of these agents after EVS (OR 6.91), bipolar ES (OR 2.41), and UD (OR 1.96), than with traditional C-A-T. Some of these agents are expensive and generate additional cost to an already expensive EBD treatment.

\section{Methodological considerations}

One strength of this work was the in vivo animal model on rat (Papers I-III) allowed precise dissection close to the nerves with the different EBD. The normal morphology in the control nerves suggested the morphological damage observed in the nerves after the EBD procedures was not the result of the process used to prepare the nerves, which was a further strength of the study. However, the muscle twitches from monopolar ES reduced precision and combined with the lack of temperature measurements could constitute limitations to the study (Papers I-III). In addition, the EMG amplitude was used to detect nerve injury; this also have been done with EMG signal configuration, signal duration, and latency. Another limitation was the species differences, only rarely can the same experiment be performed on humans and on experimental animals. The studies analyzed outcomes of myelinated nerves; however, for example, the neurovascular bundle in the pelvis contains unmyelinated parasympathic nerve fibers. Many health effects are multifactorial, and experimental models are based on one artificial cause.

In Paper II the advantages of the study are the precise temperature measurement, exact activation times and an indirect distance estimation is used to get accurate maximum temperature elevation and calculate thermal doses. In Paper III the advantages is that data from the previous papers (I and II) is reproduced in a different laboratory setting, in another country, and that the nerve injuries are evaluated with EM. A limitation is that only a few nerves demonstrate injury in EM. The study is underpowered for detection differences of EM injuries between the EBD. 
Data were extracted from the Scandinavian Quality Register for Thyroid, Parathyroid and Adrenal Surgery (SQRTPA) (Paper IV) for this multicenter study including prospective data of usage of EBD in different clinical settings from both specialized and non-specialized centers. The register coverage in 2009 was $88 \%$ of all thyroid procedures, and included around 80\% of all surgery units in Sweden [139]. The validity of the register is continuously monitored. However, as the register board only approved the specific registration of surgical instruments one year before the application of data that were used in the study (Paper IV), this could be considered a limitation. With an assumed incidence of RLN injuries of 1-3\%, the number of procedures was too short; consequently, the study was underpowered for detecting the differences between the EBD. Data on individual surgeon's experience and volume are lacking, as are factors associated with outcome measures in thyroid surgery $[140,141]$. Another limitation was the missing data values at the 6-month follow-up. 


\section{Conclusions}

- Functional loss of nerve function (Papers I-IV) and severe morphological damage (Papers I-III) were uncommon in all groups, despite activation of EBD close to the nerves.

- The experimental model functioned and was reproducible for assessing thermal effects on nerve tissue after close nerve activation of electrosurgery and ultrasonic dissection.

- The risk of collateral thermal nerve injury was higher with bipolar electrosurgery than with an ultrasonically activated instrument.

- The thermal effects strongly depended on the distance to the activated $\mathrm{EBD}$ and the activation time.

- The clinical multicenter quality register study on thyroid surgery (Paper IV) indicated a lower risk for iatrogenic parathyroid dysfunction with ultrasonic dissection than with electrosurgery.

- The effects on operation time and the use of expensive topical hemostatic agents differed between energy-based surgical instruments, and will influence total cost.

- Future investigator-initiated trials are needed, as technology is evolving quickly and EBD are used in additional surgical areas. 


\section{Future aspects}

While EBDs contribute to safer and more efficient surgery, they can also cause serious complications. Technology is advancing so quickly that even as we implement a new EBD in surgery, new technologies to replace it are close behind. The new sciences are not only producing remarkable new opportunities, but also new risks as the knowledge of the surgeons does not always develop at the same pace. At today's rate of change, every surgeon will see not one, but many different new instruments during their career - the practice of surgery is changing faster than any time in the past.

To use EBDs to their fullest potential, prevent complications, and improve the safety of surgery and its outcomes, users need to understand the principles of each device, how it is set up, how it interfaces with other devices, and its potential pitfalls. In the future, parts of the training programs for EBDs could be in simulator. Today, surgeons try new technologies during operation on their patients. The incidence of injury related to EBDs is reported ton 1-2 per 1000 operations. This is comparable to other surgical safety issues, including the incidence of retained surgical foreign bodies (0.7-1 per 1000 operations) [142] and wrong site surgery (0.1 per 1000 operations) [143]. Appropriate training programs concerning EBDs for surgeons and nurses may be implemented to keep up with the new technologies would be of value in the future.

The interaction between EBD and tissues is poorly understood, and future research in this field is indicated to help surgeons optimize the applications of these devices. UD thermal spread seems to be more controllable (more linear), but perhaps less "self-limited" compared to ES.

Additional investigator initiated prospective trials is needed, this is of relevance when comparing surgical technologies designed by different manufacturers. Many of the previous studies have been supported by the manufacturers. Interesting study fields could be for example in the SQRTPA, the Swedish Colorectal Register and following prostatectmies, to follow the effect of collateral thermal injuries during more than one year. 
Cost remains a universal issue with the current new EBDs and further cost-benefit analyses are needed. Previously reported analyses of economic comparisons of these techniques have not yielded concordant results [144][145]. 


\section{Sammanfattning på Svenska}

Redan under antiken använde man energi från brännjärn för att behandla tumörer och stoppa blödningar. Under 1800-talet började elektricitet användas där själva instrumentet hettades av elektriciteten, innan det användes på vävnaden. Vid början av 1900-talet framtogs de första instrumenten som skickade elektricitet in i vävnaden, därmed var den moderna "diatermin" född. De flesta kirurgiska ingrepp idag involverar ett kirurgiskt instrument som använder någon form av energi för att dela och koagulera vävnad. Energin från dessa instrument leder till en värmespridning i själva operationsområdet som kan leda till oönskade skador hos patienten. Efter operation av ändtarmscancer och prostatacancer får tex ca hälften av patienterna svårigheter med vattenkastningen. Vid operationer på sköldkörteln drabbas ca $2 \%$ av patienterna av bestående skador som påverkar rösten i olika utsträckning. Naturligtvis beror inte dessa skador bara på det kirurgiska instrumentet, utan även på kirurgisk teknik och ingreppets art.

Det finns olika slags kirurgiska instrument, de i dag vanligaste använder elektricitet eller ultraljudsenergi. Kunskapen hos kirurger angående hur dessa instrument fungerar kan förbättras, vilket även visats i vetenskapliga studier. Det räcker inte med "att de fungerar", då risken för komplikationer ökar om kirurgen inte förstår vilka egenskaper/begränsningar respektive instrument har.

Olika former av energi leder till olika slags vävnadseffekter, vilket är fokus för detta avhandlings arbete. Tre av studierna i avhandlingen är gjorda experimentellt på djurmodell, och den avslutande studien är en nationell patientregister-studie vid sköldkörteloperationer.

I studie I undersöktes om risken var större för nervskador vid användandet av elektriska diatermier i jämförelse med ultraljudsgenererade dissektions instrument. Studien gjordes på en råttmodell där den kirurgiska dissektionen skedde nära en nerv i råttans ben med diatermi respektive ultraljud. Vi mätte nervpotential före och efter försöken samt samlade in nerverna för mikroskopisk undersökning efter de genomförda experimenten. De histologiska preparaten bedömdes av en patolog 
med specialisering inom nerv patologi. Resultaten visade en signifikant reduktion av nerv-potentialen efter användandet av elektriska diatermier i jämförelse med ultraljudsteknik. Mikroskopiska bedömningarna visade också en mindre andel nervskador i ultraljudsgruppen.

Studie II gjordes på samma djurmodell som studie I. I denna studie mättes, förutom nervpotential och mikroskopiska skador på nerv, även värmespridning i vävnad under försöken. Vi samarbetade med en matematiker och fysiker från institutet för mätkalibrering $i$ Braunschweig, Tyskland. Under försöken använde vi en avancerad temperaturmätning där maximal temperatur stegring, termal dos och värmespridningen i vävnaden mättes vid användandet av elektriska diatermier och ultraljudsbaserad dissektionsutrustning. Resultaten visade att den maximala temperaturen och termala dosen var signifikant högre efter försöken med elektriska diatermier jämfört med ultraljudsteknik. Mikroskopiska bedömningarna visade även i detta experiment en mindre andel nervskador i ultraljudsgruppen.

Studie III genomfördes på samma djurmodell som i studie I och II. Vi fick här möjligheten att samarbeta med en Belgisk forskargrupp och där igenom få tillgång till elektronmikroskopi för att bedöma nervskadorna efter kirurgi. Som i studie II mättes även temperaturen i vävnaden samt nerv potentialen före och efter försöken. Elektronmikroskopi visade att endast ett fåtal nerver var skadade, men fler skador sågs i elektriska diatermingruppen. Temperartur resultaten följde våra resultat från studie II, där elektrodiatermin ledde till högre värden jämfört med ultraljudsdissektions utrustning.

Studie IV är en multicenter register studie, där de flesta sjukhus i Sverige deltagit genom att skicka in sina resultat efter sköldkörteloperationer. Studien genomfördes efter tillstånd från Registerstyrelsen. Vi har i denna studie jämfört risken för komplikationer vid användande av olika energigivande dissektionsutrustningar inbördes och mot den traditionella "dela och knyt" tekniken. Iatrogena nervskador efter dessa operationer utgör en ovanlig, men tråkig komplikation till sköldkörteloperationer. 
En vanligare komplikation är påverkan av kalkvärdet, efter skador på bisköldkörtelarna i samband med operationen.

Resultaten visade att användandet av dessa redskap i samband med sköldkörteloperationer är vanligt. Det förelåg skillnader mellan grupperna. Ultraljudsdissektion ledde till signifikant färre postoperativa komplikationer jämfört med de elektriska modaliteterna, samt kortare operationstider. Användandet av dyra "vävnadsplåster", som minskar risken av postoperativ blödning, var högre i alla dissektions grupper som använder energi i jämförelse med dela och knyt gruppen. Nervskadorna var få i samtliga grupper.

\section{Slutsatser}

De tre experimentella studierna påvisade en lägre risk för kollaterala värmerelaterade nervskador efter ingrepp med ultraljudsdissektions utrustning i jämförelse med traditionell elektrodiatermi, vilket talar till förmån för användande av ultraljud vid operationer i närheten av nervvävnad. I den kliniska registerstudien sågs minskade operationstider, minskade risker för kalkrelaterade komplikationer efter kirurgi med ultraljudsdissektion.

Kunskapen hos kirurger and dessa värmealstrande redskap behöver förbättras. Detta är ett ämne som borde beröras i samband med en kirurg-utbilning, vilket så inte är fallet i nuläget. Risken för skador på nerverna som innerverar stämbanden var låg i samtliga grupper. Även om risken var något högre i de grupper där elektricitet använts, var skillnaderna för små för att dra några säkra slutsatser. 


\section{Acknowledgement}

This thesis has not been a straight journey. It has been more like a rollercoaster. Like the longest rollercoaster, ever. So many people have contributed to this ride and in making it coming to its final stop. I wish to express my sincere gratitude to all of you in making it happen.

Kenth Johansson, my friend and main supervisor. For always supporting and thinking the best of me, being enthusiastic and having more persistence than an Olympic marathon runner. The part of being my main supervisor fades in the shadow of your friend- and mentorship. I will always be truly grateful for your support.

Leif Bergkvist, my co-tutor. Ask Leif any tricky question and you have a bright answer within seconds. Thank you for letting me share your excellent scientific brain, your linguistic instinct, and for the unfailing support.

Oliver Gimm, my co-tutor, for good scientific advices and support.

My co-authors Kristian Koch, Claes Nordborg, Sivert Lindström, Lars Brudin, Thierry Defechereux, Erik Nordenström, Svante Jansson, and Phillipe Wagner, for teaching me all about nerves, temperature spread, statistics and the wonder of the thyroid gland.

Jerzy Leppert, former head of Center for Clinical Research in Västerås, for all freindship and support during the years, for many challenging tennis-rallies and for constant reminding me that the impossible is not impossible. You will always be an inspiration in your way of thinking and in the way you are "networking".

Mats Enlund, the head of Center for Clinical Research in Västerås, for giving me a chance at CKF, for providing the means necessary to finish this thesis and for standing up for CKF at sometimes turbulent times. 
Johan D. Söderholm, professor and dean at Hälsouniversitet Linköping, for being the right person at the right place. I will always be grateful for you coming to my aid, at numerous occasions.

CKF, for opening up your arms for me and letting me be a part of this great place. Thanks for helping me out in this research jungle. Special thanks to Maria Dell Uva Karlsson, Michaela Eriksson, for brightening my days, always helping in and in doing so with a smile.

I would also like to thank all significant $\mathrm{P}$-values that have presented themselves during these years.

Magdalena Maltebo, Emeli Condén and Lena Burström, former PhD students, for being my one and only "researchgroup". Thank you for making me believe that this was possible and for all the laughs along the way!!

Anders Nilsson, current head of the Department of Surgery, for providing a creative and supportive atmosphere to work in, for being positive, enthusiastic and encouraging. For him being probably the only "chief" that has bought a "rökmaskin" to any surgical department.

All my colleagues at the Department of Surgery, Västerås, for their friendship and shared laughs at different "fika-rooms" around the hospital, for making it such nice working environment.

Abbas Chabok, for all encouragement, not only in finishing my thesis, and for providing me with the necessary time. Kennet Smedh, for letting me be a part of a fantastic unit, for accurate tutoring and support. Katarina Timander for being you, and for all life-giving stories during surgery. You all have made me a surgeon with a perspective wider than just the wound. 
Yvette Andersson and Maziar Nikberg for real friendship and for being the best of colleagues. I do feel very fortunate having you around all days at work and in feeling your support through the path of life.

Eva Strand, my loyal and wise friend. For caring and seeing all people, in understanding that the little things in life are the important ones, and for always being there for me and my family.

\section{Henrik Andersson, Emmanuel Ezra, Mårten "K” Sandstedt, Andreas}

Ranhem and Anders Frydén, through good and through bad times, you have been there with enduring support and with true friendship helping me to stay sane through these years!

My dad Jörgen, Ann-Charlotte, my sisters Madeleine and Gabriella, together we make a family. Thank you for all support, and none of this would have been possible without you.

Stina, my sister (and Eskil, Fyra and Pixie) for making me think outside the box, for pushing me (and my dad) in a healthy nonacademic direction! For making me appreciate things outside my comfort zone, for supporting your computer-idiot-brother in hard and easy tasks with your brilliant art design skills.

Tom and Stella, you have my endless love and will always remind me what is most important in life, you. 


\section{References}

1. Lange, M.M., et al., Urinary dysfunction after rectal cancer treatment is mainly caused by surgery. Br J Surg, 2008. 95(8): p. 1020-8.

2. Sterk, P., et al., Voiding and sexual dysfunction after deep rectal resection and total mesorectal excision: prospective study on 52 patients. Int J Colorectal Dis, 2005. 20(5): p. 423-7.

3. Eveno, C., et al., Sexual and urinary dysfunction after proctectomy for rectal cancer. J Visc Surg, 2010. 147(1): p. e21-30.

4. Haglind, E., et al., Urinary Incontinence and Erectile Dysfunction After Robotic Versus Open Radical Prostatectomy: A Prospective, Controlled, Nonrandomised Trial. Eur Urol, 2015. 68(2): p. 216-25.

5. Carlsson, S., et al., Population-based study of long-term functional outcomes after prostate cancer treatment. BJU Int, 2015.

6. Joosten, U., et al., [Risk factors and follow-up of recurrent laryngeal nerve paralysis after first surgeries of benign thyroid diseases. Results of a retrospective analysis of 1,556 patients]. Zentralbl Chir, 1997. 122(4): p. 236-45.

7. Wagner, H.E. and C. Seiler, Recurrent laryngeal nerve palsy after thyroid gland surgery. Br J Surg, 1994. 81(2): p. 226-8.

8. Shindo, M.L., et al., Management of invasive well-differentiated thyroid cancer: an American Head and Neck Society consensus statement. AHNS consensus statement. Head Neck, 2014. 36(10): p. 1379-90.

9. Rosato, L., et al., Complications of thyroid surgery: analysis of a multicentric study on 14,934 patients operated on in Italy over 5 years. World J Surg, 2004. 28(3): p. 271-6.

10. Bergenfelz, A., et al., Complications to thyroid surgery: results as reported in a database from a multicenter audit comprising 3,660 patients. Langenbecks Arch Surg, 2008. 393(5): p. 667-73.

11. Feldman, L.S., et al., Surgeons don't know what they don't know about the safe use of energy in surgery. Surg Endosc, 2012. 26(10): p. 2735-9. 
12. Tulikangas, P.K., et al., Gross and histologic characteristics of laparoscopic injuries with four different energy sources. Fertil Steril, 2001. 75(4): p. 806-10.

13. Box, G.N., et al., Comparative study of in vivo lymphatic sealing capability of the porcine thoracic duct using laparoscopic dissection devices. J Urol, 2009. 181(1): p. 387-91.

14. Sutton, P.A., et al., Comparison of lateral thermal spread using monopolar and bipolar diathermy, the Harmonic Scalpel and the Ligasure. Br J Surg, 2010. 97(3): p. 428-33.

15. Garas, G., et al., Which hemostatic device in thyroid surgery? A network meta-analysis of surgical technologies. Thyroid, 2013. 23(9): p. 1138-50.

16. Phillips, C.K., et al., Tissue response to surgical energy devices. Urology, 2008. 71(4): p. 744-8.

17. Perko, Z., et al., Lateral thermal damage to rat abdominal wall after harmonic scalpel application. Surg Endosc, 2006. 20(2): p. 322-4.

18. Contin, P., et al., ENERgized vessel sealing systems versus CONventional hemostasis techniques in thyroid surgery--the ENERCON systematic review and network meta-analysis. Langenbecks Arch Surg, 2013. 398(8): p. 1039-56.

19. Cirocchi, R., et al., Meta-analysis of thyroidectomy with ultrasonic dissector versus conventional clamp and tie. World J Surg Oncol, 2010. 8: p. 112.

20. Yao, H.S., et al., Prospective clinical trials of thyroidectomy with LigaSure vs conventional vessel ligation: a systematic review and meta-analysis. Arch Surg, 2009. 144(12): p. 1167-74.

21. O'Connor, J.L. and D.A. Bloom, William T. Bovie and electrosurgery. Surgery, 1996. 119(4): p. 390-6.

22. Stillings, D., John Wesley: philosopher of electricity. Med Instrum, 1973. 7(5): p. 307.

23. d'Arsonal, A., Action physiologique des courants alternatis a grande frequence. Arch Physiol Porm Pathol., 1893(25): p. 401.

24. Schwaitzberg, S., Evolutions and revolutions in surgical energy. The fundamental use of surgical energy (FUSE) manual, ed. F.P. Feldman LS, Jones DB. 2012, New York: Springer. 
25. Cushing H, B.W., Electrosurgery as an aid to the removal of intracranial tumors. Surg Gynecol Obstet., 1928(47): p. 751-84.

26. Hambley, R., et al., Wound healing of skin incisions produced by ultrasonically vibrating knife, scalpel, electrosurgery, and carbon dioxide laser. J Dermatol Surg Oncol, 1988. 14(11): p. 1213-7.

27. Amaral, J.F., Laparoscopic cholecystectomy in 200 consecutive patients using an ultrasonically activated scalpel. Surg Laparosc Endosc, 1995. 5(4): p. 255-62.

28. Massarweh, N.N., N. Cosgriff, and D.P. Slakey, Electrosurgery: history, principles, and current and future uses. J Am Coll Surg, 2006. 202(3): p. 520-30.

29. Morris, M.L., et al., Electrosurgery in gastrointestinal endoscopy: principles to practice. Am J Gastroenterol, 2009. 104(6): p. 1563-74.

30. Albert M, E.C., Fleshman J, Margolin D, Ng PC, Podnos YD, The effective use of the ENSEAL system in colorectal surgery. 2010.

31. Brill, A.I., Bipolar electrosurgery: convention and innovation. Clin Obstet Gynecol, 2008. 51(1): p. 153-8.

32. McAnena, O.J. and P.D. Willson, Diathermy in laparoscopic surgery. Br J Surg, 1993. 80(9): p. 1094-6.

33. Hubner, M., et al., Prospective randomized study of monopolar scissors, bipolar vessel sealer and ultrasonic shears in laparoscopic colorectal surgery. Br J Surg, 2008. 95(9): p. 1098-104.

34. Hruby, G.W., et al., Evaluation of surgical energy devices for vessel sealing and peripheral energy spread in a porcine model. J Urol, 2007. 178(6): p. 2689-93.

35. Balague, C., [Hemostasis and technology. Energy. Development of new technologies]. Cir Esp, 2009. 85 Suppl 1: p. 15-22.

36. Slakey, D.P., Laparoscopic liver resection using a bipolar vesselsealing device: LigaSure. HPB (Oxford), 2008. 10(4): p. 253-5.

37. Campbell, P.A., et al., Real-time thermography during energized vessel sealing and dissection. Surg Endosc, 2003. 17(10): p. 1640-5.

38. Harold, K.L., et al., Comparison of ultrasonic energy, bipolar thermal energy, and vascular clips for the hemostasis of small-, medium-, and large-sized arteries. Surg Endosc, 2003. 17(8): p. 1228-30. 
39. Newcomb, W.L., et al., Comparison of blood vessel sealing among new electrosurgical and ultrasonic devices. Surg Endosc, 2009. 23(1): p. 90-6.

40. van de Berg, N.J., et al., Energetic soft-tissue treatment technologies: an overview of procedural fundamentals and safety factors. Surg Endosc, 2013. 27(9): p. 3085-99.

41. Voyles, C.R. and R.D. Tucker, Education and engineering solutions for potential problems with laparoscopic monopolar electrosurgery. Am J Surg, 1992. 164(1): p. 57-62.

42. Montero, P.N., et al., Insulation failure in laparoscopic instruments. Surg Endosc, 2010. 24(2): p. 462-5.

43. Vilos, G., K. Latendresse, and B.S. Gan, Electrophysical properties of electrosurgery and capacitive induced current. Am J Surg, 2001. 182(3): p. 222-5.

44. Gossot, D., et al., Ultrasonic dissection for endoscopic surgery. The E.A.E.S. Technology Group. Surg Endosc, 1999. 13(4): p. 412-7.

45. Riegler M, C.E., Bischof G, Review: update and economic aspects of the harmonic scalpel in general surgery. Eur Surg, 2004. 36(8).

46. Smith, R. and R. Pasic, The role of vessel sealing technologies in laparoscopic surgery. Surg Technol Int, 2008. 17: p. 208-12.

47. Lee, S.J. and K.H. Park, Ultrasonic energy in endoscopic surgery. Yonsei Med J, 1999. 40(6): p. 545-9.

48. Devassy, R., S. Gopalakrishnan, and R.L. De Wilde, Surgical Efficacy Among Laparoscopic Ultrasonic Dissectors: Are We Advancing Safely? A Review of Literature. J Obstet Gynaecol India, 2015. 65(5): p. 293-300.

49. Noble, E.J., et al., Experimental comparison of mesenteric vessel sealing and thermal damage between one bipolar and two ultrasonic shears devices. Br J Surg, 2011.98(6): p. 797-800.

50. Yildirim, O., et al., Ultrasonic harmonic scalpel in total thyroidectomies. Adv Ther, 2008. 25(3): p. 260-5.

51. Sietses, C., et al., Ultrasonic energy vs monopolar electrosurgery in laparoscopic cholecystectomy: influence on the postoperative systemic immune response. Surg Endosc, 2001. 15(1): p. 69-71. 
52. Kim, FJ., et al., Temperature safety profile of laparoscopic devices: Harmonic ACE (ACE), Ligasure V (LV), and plasma trisector (PT). Surg Endosc, 2008. 22(6): p. 1464-9.

53. Willson, P.D., et al., Electrosurgical safety during laparoscopic surgery. Minimally Invasive Therapy \& Allied Technologies, 1995. 4(4): p. 195-201.

54. Aksan, A., J.J. McGrath, and D.S. Nielubowicz, Jr., Thermal damage prediction for collagenous tissues part I: a clinically relevant numerical simulation incorporating heating rate dependent denaturation. J Biomech Eng, 2005. 127(1): p. 85-97.

55. Stylianopoulos, T., A. Aksan, and V.H. Barocas, A structural, kinetic model of soft tissue thermomechanics. Biophys J, 2008. 94(3): p. 717-25.

56. Govekar, H.R., et al., Effect of monopolar radiofrequency energy on pacemaker function. Surg Endosc, 2012. 26(10): p. 2784-8.

57. Hideki N, M.N., Norihiro $\mathrm{Y}$ et al, Electrosurgical devices for abdominal surgery: compparison between monopolar devices and bipolar scissors. Surg Ther, 2003. 89(1): p. 8-13.

58. Lantis, J.C., II, et al., Comparison of coagulation modalities in surgery. J Laparoendosc Adv Surg Tech A, 1998. 8(6): p. 381-94.

59. Davidoff, A.M., et al., Mechanisms of major biliary injury during laparoscopic cholecystectomy. Ann Surg, 1992. 215(3): p. 196-202.

60. Ata, A.H., et al., Distal thermal injury from monopolar electrosurgery. Surg Laparosc Endosc, 1993. 3(4): p. 323-7.

61. Diamantis, T., et al., Comparison of monopolar electrocoagulation, bipolar electrocoagulation, Ultracision, and Ligasure. Surg Today, 2006. 36(10): p. 908-13.

62. Mantke, R., et al., Efficacy and safety of 5-mm-diameter bipolar and ultrasonic shears for cutting carotid arteries of the hybrid pig. Surg Endosc, 2011. 25(2): p. 577-85.

63. Edelman, D.S. and S.W. Unger, Bipolar versus monopolar cautery scissors for laparoscopic cholecystectomy: a randomized, prospective study. Surg Laparosc Endosc, 1995. 5(6): p. 459-62.

64. Person, B., et al., Comparison of four energy-based vascular sealing and cutting instruments: A porcine model. Surg Endosc, 2008. 22(2): p. 534-8. 
65. Nduka, C.C., et al., Cause and prevention of electrosurgical injuries in laparoscopy. J Am Coll Surg, 1994. 179(2): p. 161-70.

66. Overbey, D.M., et al., Surgical Energy-Based Device Injuries and Fatalities Reported to the Food and Drug Administration. J Am Coll Surg, 2015. 221(1): p. 197-205 e1.

67. Govekar, H.R., et al., Residual heat of laparoscopic energy devices: how long must the surgeon wait to touch additional tissue? Surg Endosc, 2011. 25(11): p. 3499-502.

68. Voutilainen, P.E. and C.H. Haglund, Ultrasonically activated shears in thyroidectomies: a randomized trial. Ann Surg, 2000. 231(3): p. 322-8.

69. Siperstein, A.E., E. Berber, and E. Morkoyun, The use of the harmonic scalpel vs conventional knot tying for vessel ligation in thyroid surgery. Arch Surg, 2002. 137(2): p. 137-42.

70. Petrakis, I.E., et al., LigaSure versus clamp-and-tie thyroidectomy for benign nodular disease. Head Neck, 2004. 26(10): p. 903-9.

71. Lang, B.H., P.C. Yih, and G.K. Hung, Does using an energized device in open thyroidectomy reduce complications? J Surg Res, 2013. 181(1): p. e23-9.

72. Abboud, B., et al., Risk factors for posthyroidectomy hypocalcemia. J Am Coll Surg, 2002. 195(4): p. 456-61.

73. Wang, T.S., S.A. Roman, and J.A. Sosa, Postoperative calcium supplementation in patients undergoing thyroidectomy. Curr Opin Oncol, 2012. 24(1): p. 22-8.

74. Sitges-Serra, A., et al., Outcome of protracted hypoparathyroidism after total thyroidectomy. Br J Surg, 2010. 97(11): p. 1687-95.

75. Thomusch, O., et al., The impact of surgical technique on postoperative hypoparathyroidism in bilateral thyroid surgery: a multivariate analysis of 5846 consecutive patients. Surgery, 2003. 133(2): p. 180-5.

76. Erbil, Y., et al., Predictive factors for recurrent laryngeal nerve palsy and hypoparathyroidism after thyroid surgery. Clin Otolaryngol, 2007. 32(1): p. 32-7.

77. Koh, Y.W., et al., Endoscopic thyroidectomy via a unilateral axillobreast approach without gas insufflation for unilateral benign thyroid lesions. Surg Endosc, 2009. 23(9): p. 2053-60. 
78. Owaki, T., et al., The ultrasonic coagulating and cutting system injures nerve function. Endoscopy, 2002. 34(7): p. 575-9.

79. Snyder, S.K., et al., Elucidating mechanisms of recurrent laryngeal nerve injury during thyroidectomy and parathyroidectomy. J Am Coll Surg, 2008. 206(1): p. 123-30.

80. Varaldo, E., et al., Neurological complications in thyroid surgery: a surgical point of view on laryngeal nerves. Front Endocrinol (Lausanne), 2014. 5: p. 108.

81. Teitelbaum, B.J. and B.L. Wenig, Superior laryngeal nerve injury from thyroid surgery. Head Neck, 1995. 17(1): p. 36-40.

82. Hurtado-Lopez, L.M., et al., Importance of the intraoperative identification of the external branch of the superior laryngeal nerve during thyroidectomy: electromyographic evaluation. Thyroid, 2005. 15(5): p. 449-54.

83. Aluffi, P., et al., Post-thyroidectomy superior laryngeal nerve injury. Eur Arch Otorhinolaryngol, 2001. 258(9): p. 451-4.

84. Lee, H.S., et al., Patterns of Post-thyroidectomy Hemorrhage. Clin Exp Otorhinolaryngol, 2009. 2(2): p. 72-7.

85. Paim, C.R., et al., Post lymphadenectomy complications and quality of life among breast cancer patients in Brazil. Cancer Nurs, 2008. 31(4): p. 302-9; quiz 310-1.

86. Duncan, M.A., et al., Incidence, recovery, and management of serratus anterior muscle palsy after axillary node dissection. Phys Ther, 1983. 63(8): p. 1243-7.

87. Adriaenssens, N., et al., Scapula alata in early breast cancer patients enrolled in a randomized clinical trial of post-surgery short-course image-guided radiotherapy. World J Surg Oncol, 2012. 10: p. 86.

88. Nevola Teixeira, L.F., et al., Incidence, predictive factors, and prognosis for winged scapula in breast cancer patients after axillary dissection. Support Care Cancer, 2014. 22(6): p. 1611-7.

89. Belmonte, R., et al., Long thoracic nerve injury in breast cancer patients treated with axillary lymph node dissection. Support Care Cancer, 2015. 23(1): p. 169-75.

90. Paci, E., et al., Long-term sequelae of breast cancer surgery. Tumori, 1996. 82(4): p. 321-4. 
91. Meininger, A.K., B.F. Figuerres, and B.A. Goldberg, Scapular winging: an update. J Am Acad Orthop Surg, 2011. 19(8): p. 453-62.

92. Currie, A., et al., Ultrasonic dissection versus electrocautery in mastectomy for breast cancer - a meta-analysis. Eur J Surg Oncol, 2012. 38(10): p. 897-901.

93. Bohm, D., et al., Prospective randomized comparison of conventional instruments and the Harmonic Focus $((R))$ device in breastconserving therapy for primary breast cancer. Eur J Surg Oncol, 2012. 38(2): p. 118-24.

94. Cortadellas, T., et al., Electrothermal bipolar vessel sealing system in axillary dissection: a prospective randomized clinical study. Int J Surg, 2011. 9(8): p. 636-40.

95. Bill-Axelson, A., et al., Radical prostatectomy versus watchful waiting in early prostate cancer. N Engl J Med, 2011. 364(18): p. 1708-17.

96. Ayyathurai, R., et al., Factors affecting erectile function after radical retropubic prostatectomy: results from 1620 consecutive patients. BJU Int, 2008. 101(7): p. 833-6.

97. Takenaka, A., et al., Influence of nerve-sparing procedure on early recovery of urinary continence after laparoscopic radical prostatectomy. J Endourol, 2009. 23(7): p. 1115-9.

98. Marien, T.P. and H. Lepor, Does a nerve-sparing technique or potency affect continence after open radical retropubic prostatectomy? BJU Int, 2008. 102(11): p. 1581-4.

99. Tzou, D.T., et al., The failure of a nerve sparing template to improve urinary continence after radical prostatectomy: attention to study design. Urol Oncol, 2009. 27(4): p. 358-62.

100. Walz, J., et al., A critical analysis of the current knowledge of surgical anatomy related to optimization of cancer control and preservation of continence and erection in candidates for radical prostatectomy. Eur Urol, 2010. 57(2): p. 179-92.

101. Mebust, W.K., et al., Transurethral prostatectomy: immediate and postoperative complications. A cooperative study of 13 participating institutions evaluating 3, 885 patients. J Urol, 1989. 141(2): p. 243-7. 
102. Poulakis, V., et al., Erectile dysfunction after transurethral prostatectomy for lower urinary tract symptoms: results from a center with over 500 patients. Asian J Androl, 2006. 8(1): p. 69-74.

103. Nesbakken, A., et al., Bladder and sexual dysfunction after mesorectal excision for rectal cancer. Br J Surg, 2000. 87(2): p. 206-10.

104. Quah, H.M., et al., Bladder and sexual dysfunction following laparoscopically assisted and conventional open mesorectal resection for cancer. Br J Surg, 2002. 89(12): p. 1551-6.

105. Ahlering, T.E., D. Skarecky, and J. Borin, Impact of cautery versus cautery-free preservation of neurovascular bundles on early return of potency. J Endourol, 2006. 20(8): p. 586-9.

106. Lepor, H., et al., Precise localization of the autonomic nerves from the pelvic plexus to the corpora cavernosa: a detailed anatomical study of the adult male pelvis. J Urol, 1985. 133(2): p. 207-12.

107. Walsh, P.C., H. Lepor, and J.C. Eggleston, Radical prostatectomy with preservation of sexual function: anatomical and pathological considerations. Prostate, 1983. 4(5): p. 473-85.

108. Brouillette, J.N., E. Pryor, and T.A. Fox, Jr., Evaluation of sexual dysfunction in the female following rectal resection and intestinal stoma. Dis Colon Rectum, 1981. 24(2): p. 96-102.

109. Bambrick, M., et al., Sexual function following restorative proctocolectomy in women. Dis Colon Rectum, 1996. 39(6): p. 610-4.

110. Sapareto, S.A. and W.C. Dewey, Thermal dose determination in cancer therapy. Int J Radiat Oncol Biol Phys, 1984. 10(6): p. 787-800.

111. Jacobs, J.M. and S. Love, Qualitative and quantitative morphology of human sural nerve at different ages. Brain, 1985. 108 ( Pt 4): p. 897-924.

112. Cordón, C., et al., A randomized, prospective, parallel group study comparing the Harmonic Scalpel to electrocautery in thyroidectomy. Surgery, 2005. 137(3): p. 337-41.

113. Miccoli, P., et al., Randomized controlled trial of harmonic scalpel use during thyroidectomy. Arch Otolaryngol Head Neck Surg, 2006. 132(10): p. 1069-73. 
114. Rahbari, R., et al., Prospective randomized trial of ligasure versus harmonic hemostasis technique in thyroidectomy. Ann Surg Oncol, 2011. 18(4): p. 1023-7.

115. Ecker, T., et al., Hemostasis in thyroid surgery: harmonic scalpel versus other techniques--a meta-analysis. Otolaryngol Head Neck Surg, 2010. 143(1): p. 17-25.

116. Lang, B.H., et al., A systematic review and meta-analysis comparing the efficacy and surgical outcomes of total thyroidectomy between harmonic scalpel versus ligasure. Ann Surg Oncol, 2013. 20(6): p. 1918-26.

117. Salanti, G., et al., Evaluation of networks of randomized trials. Stat Methods Med Res, 2008. 17(3): p. 279-301.

118. Cipriani, A., et al., What is a multiple treatments meta-analysis? Epidemiol Psychiatr Sci, 2012. 21(2): p. 151-3.

119. Koch, C., et al., Determination of temperature elevation in tissue during the application of the harmonic scalpel. Ultrasound Med Biol, 2003. 29(2): p. 301-9.

120. Eberli, D., et al., Thermal spread of vessel-sealing devices evaluated in a clinically relevant in vitro model. Urol Int, 2011. 86(4): p. 476-82.

121. Goldstein, S.L., et al., Comparison of thermal spread after ureteral ligation with the Laparo-Sonic ultrasonic shears and the Ligasure system. J Laparoendosc Adv Surg Tech A, 2002. 12(1): p. 61-3.

122. Gillespie, M.B., et al., Neural outcomes after plasma knife dissection: a pathologic study and clinical correlation. Head Neck, 2010. 32(10): p. 1321-7.

123. Tirelli, G., et al., Harmonic Scalpel and Electrothermal Bipolar Vessel Sealing System in Head and Neck Surgery: A Prospective Study on Tissue Heating and Histological Damage on Nerves. Ann Otol Rhinol Laryngol, 2015.

124. Madani, A., et al., Fundamental Use of Surgical Energy (FUSE): a curriculum on surgical energy-based devices. Surg Endosc, 2014. 28(9): p. 2509-12.

125. Kinoshita, T., et al., Experimental study on heat production by a 23.5- $\mathrm{kHz}$ ultrasonically activated device for endoscopic surgery. Surg Endosc, 1999. 13(6): p. 621-5. 
126. Rubino, L.J., et al., Healing of iatrogenic skeletal muscle wounds is affected by incision device. Surg Innov, 2010. 17(2): p. 85-91.

127. Usas, A., et al., Use of an ultrasonic blade facilitates muscle repair after incision injury. J Surg Res, 2011. 167(2): p. e177-84.

128. Nanduri, B., et al., Ultrasonic incisions produce less inflammatory mediator response during early healing than electrosurgical incisions. PLoS One, 2013. 8(9): p. e73032.

129. Chen, C., et al., The effects of ultrasonic and electrosurgery devices on nerve physiology. British Journal of Neurosurgery, 2012. 26(6): p. 856-863.

130. Chen, C., et al., Acute and subacute effects of the ultrasonic blade and electrosurgery on nerve physiology. British Journal of Neurosurgery, 2015: p. 1-5.

131. Palanker, D.V., A. Vankov, and P. Huie, Electrosurgery with cellular precision. IEEE Trans Biomed Eng, 2008. 55(2 Pt 2): p. 838-41.

132. Emam, T.A. and A. Cuschieri, How safe is high-power ultrasonic dissection? Ann Surg, 2003. 237(2): p. 186-91.

133. Miccoli, P., et al., Evaluation of a new ultrasonic device in thyroid surgery: comparative randomized study. Am J Surg, 2010. 199(6): p. 736-40.

134. Kirdak, T., N. Korun, and H. Ozguc, Use of ligasure in thyroidectomy procedures: results of a prospective comparative study. World J Surg, 2005. 29(6): p. 771-4.

135. Dionigi, G., et al., The safety of energy-based devices in open thyroidectomy: a prospective, randomised study comparing the LigaSure $^{\mathrm{Tm}}$ (LF1212) and the Harmonic ${ }^{\circledast}$ FOCUS. Langenbecks Arch Surg, 2012. 397(5): p. 817-23.

136. Sartori, P.V., et al., Ligasure versus Ultracision in thyroid surgery: a prospective randomized study. Langenbecks Arch Surg, 2008. 393(5): p. 655-8.

137. Pons, Y., et al., Comparison of LigaSure vessel sealing system, harmonic scalpel, and conventional hemostasis in total thyroidectomy. Otolaryngol Head Neck Surg, 2009. 141(4): p. 496-501. 
138. Schiphorst, A.H., et al., Randomized clinical trial of LigaSure versus conventional suture ligation in thyroid surgery. Head Neck Oncol, 2012. 4: p. 2.

139. SQRTPA, Annual Report 2009 Scandinavian Quality Register for Thyroid, Parathyroid and Adrenal Surgery. 2010: Lund, Sweden.

140. Mourad, M., et al., Randomized clinical trial on Harmonic Focus shears versus clamp-and-tie technique for total thyroidectomy. Am J Surg, 2011. 202(2): p. 168-74.

141. Pieracci, F.M. and T.J. Fahey, 3rd, Effect of hospital volume of thyroidectomies on outcomes following substernal thyroidectomy. World J Surg, 2008. 32(5): p. 740-6.

142. Hyslop, J.W. and K.I. Maull, Natural history of the retained surgical sponge. South Med J, 1982. 75(6): p. 657-60.

143. Kwaan, M.R., et al., Incidence, patterns, and prevention of wrong-site surgery. Arch Surg, 2006. 141(4): p. 353-7; discussion 357-8.

144. Sebag, F., et al., Harmonic scalpel in multinodular goiter surgery: impact on surgery and cost analysis. J Laparoendosc Adv Surg Tech A, 2009. 19(2): p. 171-4.

145. Leonard, D.S. and C. Timon, Prospective trial of the ultrasonic dissector in thyroid surgery. Head Neck, 2008. 30(7): p. 904-8. 



\section{Papers}

The articles associated with this thesis have been removed for copyright reasons. For more details about these see:

http://urn.kb.se/resolve?urn=urn:nbn:se:liu:diva-122147 
"Man tar lite härifrån och lite därifrån och joxar ihop det så blir det lagom jox"

Astrid Lindgren 